\title{
Consumption of atmospheric methane by the Qinghai-Tibet Plateau alpine steppe ecosystem
}

\author{
Hanbo Yun ${ }^{1,2,3}$, Qingbai Wu${ }^{1}$, Qianlai Zhuang ${ }^{3}$, Anping Chen ${ }^{4}$, Tong Yu ${ }^{3}$, Zhou Lyu ${ }^{3}$, Yuzhong Yang ${ }^{1}$, Huijun Jin ${ }^{1}$, \\ Guojun Liu ${ }^{1}$, Yang $\mathrm{Qu}^{3}$, and Licheng $\mathrm{Liu}^{3}$ \\ ${ }^{1}$ State Key Laboratory of Frozen Soil Engineering, Northwest Institute of Eco-Environment and Resources, \\ Chinese Academy of Sciences, Lanzhou, Gansu 730000, China \\ ${ }^{2}$ Key Laboratory for Land Surface Process and Climate Change in Cold and Arid Regions, \\ Chinese Academy of Sciences, Lanzhou, 730000, China \\ ${ }^{3}$ Department of Earth, Atmospheric, and Planetary Sciences, Purdue University, West Lafayette, Indiana 47907, USA \\ ${ }^{4}$ Department of Forestry and Natural Resources, Purdue University, West Lafayette, Indiana 47907, USA
}

Correspondence: Qingbai Wu (qbwu@lzb.ac.cn), Qianlai Zhuang (qzhuang@purdue.edu), and Anping Chen (apchen1111@gmail.com)

Received: 28 November 2017 - Discussion started: 8 December 2017

Revised: 26 July 2018 - Accepted: 8 August 2018 - Published: 3 September 2018

\begin{abstract}
The methane $\left(\mathrm{CH}_{4}\right)$ cycle on the Qinghai-Tibet Plateau (QTP), the world's largest high-elevation permafrost region, is sensitive to climate change and subsequent freezing and thawing dynamics. Yet, its magnitudes, patterns, and environmental controls are still poorly understood. Here, we report results from five continuous year-round $\mathrm{CH}_{4} \mathrm{ob}-$ servations from a typical alpine steppe ecosystem in the QTP permafrost region. Our results suggest that the QTP permafrost region was a $\mathrm{CH}_{4}$ sink of $-0.86 \pm 0.23 \mathrm{~g} \mathrm{CH}_{4}$ $\mathrm{C} \mathrm{m}^{-2} \mathrm{yr}^{-1}$ over 2012-2016, a rate higher than that of many other permafrost areas, such as the Arctic tundra in northern Greenland, Alaska, and western Siberia. Soil temperature and soil water content were dominant factors controlling $\mathrm{CH}_{4}$ fluxes; however, their correlations changed with soil depths due to freezing and thawing dynamics. This region was a net $\mathrm{CH}_{4}$ sink in autumn, but a net source in spring, despite both seasons experiencing similar top soil thawing and freezing dynamics. The opposite $\mathrm{CH}_{4}$ sourcesink function in spring versus in autumn was likely caused by the respective seasons' specialized freezing and thawing processes, which modified the vertical distribution of soil layers that are highly mixed in autumn, but not in spring. Furthermore, the traditional definition of four seasons failed to capture the pattern of the annual $\mathrm{CH}_{4}$ cycle. We developed a new seasonal division method based on soil temperature, bacterial activity, and permafrost active layer thickness, which signifi-
\end{abstract}

cantly improved the modeling of the annual $\mathrm{CH}_{4}$ cycle. Collectively, our findings highlight the critical role of fine-scale climate freezing and thawing dynamics in driving permafrost $\mathrm{CH}_{4}$ dynamics, which needs to be better monitored and modeled in Earth system models.

\section{Introduction}

Since 2007, the global atmospheric methane concentration $\left[\mathrm{CH}_{4}\right]$ continues to rise, after remaining stable between the 1990s and 2006 (Rigby et al., 2008; IPCC, 2013; Patra and Kort, 2016). Understanding mechanisms for this recent increase requires improved knowledge of $\mathrm{CH}_{4}$ sources and sinks for regional and global $\mathrm{CH}_{4}$ budgets (Kirschke et al., 2013; Zona et al., 2016). However, estimates on global $\mathrm{CH}_{4}$ emissions and consumptions are still highly uncertain (Spahni et al., 2011; Kirschke et al., 2013). In particular, the bottom-up approach, which estimates $\mathrm{CH}_{4}$ budgets using ground observations and inventory, overestimated the global $\mathrm{CH}_{4}$ budget by 6-20 times, compared to the atmospherically constrained top-down approach (Zhu et al., 2004; Lau et al., 2015). This discrepancy is partly due to limited monitoring data and to our poor understanding of important factors regulating the production and consumption of $\mathrm{CH}_{4}$ (Whalen and Reeburgh, 1990; Dengel et al., 2013; Bohn et al., 2015). 
The Qinghai-Tibet Plateau (QTP) is the world's largest high-elevation permafrost region of $1.23 \times 10^{6} \mathrm{~km}^{2}$ (Wang et al., 2000). The QTP is currently experiencing a rapid change in climate, which affects freezing and thawing processes. The change in the freezing and thawing dynamics profoundly impacts methanotrophy and methanogenesis, which consequently impacts net $\mathrm{CH}_{4}$ fluxes (Mastepanov et al., 2013; Lau et al., 2015). However, due to the scarcity of year-round monitoring data at high temporal resolution, we still know little about the size, seasonal pattern, and underlying controls of climate and permafrost freezing and thawing and the resulting effects on $\mathrm{CH}_{4}$ exchanges in the QTP permafrost region (Cao et al., 2008; Wei et al., 2015a; Song et al., 2015). This knowledge gap also hampers our capacity to predict and understand QTP permafrost $\mathrm{CH}_{4}$ cycles under current and projected future climates.

Here, we report results from a 5-year continuous in situ monitoring of $\mathrm{CH}_{4}$ dynamics with an eddy covariance (EC) technique at the Beilu'he research station, which is a representative site for QTP permafrost heartland. The site was covered by alpine steppe vegetation from 1 January 2012 to 31 December 2016. The primary aims of this investigation are to understand (1) the long-term annual and seasonal variation in the methane budget for a typical alpine permafrost site in the QTP and (2) the environmental factors controlling these $\mathrm{CH}_{4}$ variations and possible underlying mechanisms. In addition, while the consumption and production of ecosystem methane are known through microbial activities, conventional investigations on seasonal methane fluxes usually used climate- or vegetation-defined "seasons". Therefore, a third research goal of this current study is to investigate if the classical vegetation productivity-based definition of growing season will be useful for defining the methane flux seasonality.

There are three advantages of our data acquisition system. First, the EC system recorded the data of $\mathrm{CH}_{4}$ fluxes, climate, and soil properties every half hour. As the QTP permafrost is characterized by a rapidly changing climate and rapidly changing soil freezing and thawing dynamics, even over a time period as short as 1 day, different aerobic or anaerobic soil environments that favor different types of $\mathrm{CH}_{4}$ bacteria may change (Rivkina et al., 2004; Lau et al., 2015). Thus, high-resolution in situ monitoring data enable us to quantify $\mathrm{CH}_{4}$ exchange patterns from diel to annual timescales and investigate their major environmental drivers. Second, our field investigation spanned 5 full calendar years, including both plant growing and nongrowing seasons. Observations of the plant nongrowing season, which accounts for two-thirds of a year, are very rare in current literature (Song et al., 2015). Third, the EC system we used overcame some technical problems caused by the often used static chambers, including limited representation of local site heterogeneity and additional heating of the soil surface (Chang et al., 2014; Wei et al., 2015b).

\section{Methods}

\subsection{Site description}

The research site, Beilu'he permafrost research station $\left(34^{\circ} 09^{\prime} 006^{\prime \prime} \mathrm{N}, 92^{\circ} 02^{\prime} 080^{\prime \prime} \mathrm{E}\right)$, is located in the alpine steppe continuous permafrost area of the northern QTP, about $320 \mathrm{~km}$ southwest of Golmud, Qinghai Province (Fig. 1). At an elevation of $4765 \mathrm{~m}$, the air is thin with only 0.6 standard atmospheric pressure. According to in situ observations, the site receives solar radiation of about $213.10 \mathrm{~W} \mathrm{~m}^{-2}$. The nongrowing season is long and cold, with 225 days per year having an annual air temperature of $-18^{\circ}$ on average from 2012 to 2016. The site's growing season is short and cool, with 140 days per year from 2012 to 2016 and a mean annual air temperature of $4.6^{\circ} \mathrm{C}$. According to the site drilling exploration, the permafrost depth can extend to $50-70 \mathrm{~m}$ below ground, and the thickness of the active layer (ALT) is about 2.2-4.8 $\mathrm{m}$ (Wu et al., 2010a). The soil is composed of Quaternary fine sand or silt (Table 1), overlying Triassic mudstone or weathered marl. Dominant plant species include Carex moorcroftii Falc. ex Boott, Kobresia tibetica Maxim, Androsace tanggulashanensis, and Rhodiola tibetica. Vegetation coverage is approximately $33.5 \%$ and the average plant height is $15 \mathrm{~cm}$.

\subsection{Eddy covariance observations}

We have continuously monitored $\mathrm{CH}_{4}$, carbon dioxide $\left(\mathrm{CO}_{2}\right)$, water $\left(\mathrm{H}_{2} \mathrm{O}\right)$, and heat flux using a standard EC system tower $3 \mathrm{~m}$ above the ground. $\mathrm{CH}_{4}$ flux was measured with an open-path $\mathrm{CH}_{4}$ analyzer system (Fig. 1d; LI-7700, Li-cor Inc., Lincoln, NE, USA). The precision is $5 \mathrm{ppb}$, with RMS noise at $10 \mathrm{~Hz}$ and $2000 \mathrm{ppb}$. The instrument was placed on site on 8 August 2011 and then connected to a three-dimensional sonic anemometer (heat and water flux; CSAT3, Campbell Scientific, and Logan, UT, USA; the precision is $0.1{ }^{\circ} \mathrm{C}$ with an accuracy within $1 \%$ of the reading for half-hour measurements) and an open-path infrared gas analyzer $\left(\mathrm{CO}_{2}\right.$ flux; LI-7500A, Li-cor Inc., Lincoln, NE, USA; the precision is $0.01 \mu \mathrm{mol} \mathrm{m}^{-2} \mathrm{~s}^{-1}$ with an accuracy within $1 \%$ of the reading for half-hour measurements; zero drift per degree Celsius is typically $\pm 0.1 \mathrm{ppm}$ ) on 1 January 2012, when the system worked steadily. Monitoring data were recorded and stored at $10 \mathrm{~Hz}$ using a data logger (LI7550, Li-cor Inc., Lincoln, NE, USA).

The operation, calibrations, and maintenance of the EC system followed standard procedures. To reduce the LI$7500 \mathrm{~A}$ surface heating-cooling influence on $\mathrm{CO}_{2}$ and $\mathrm{H}_{2} \mathrm{O}$ molar densities in tough environments, each year "summer style", in which the surface temperature setting was $5^{\circ} \mathrm{C}$, was used in Li-7500A from 1 May to 30 September. "Winter style", in which the surface temperature setting was $-5^{\circ} \mathrm{C}$, was used from 1 October to 30 April the next year in $\mathrm{Li}^{-}$ 7500A. Calibrations of $\mathrm{CO}_{2}$, water vapor, and dew point 

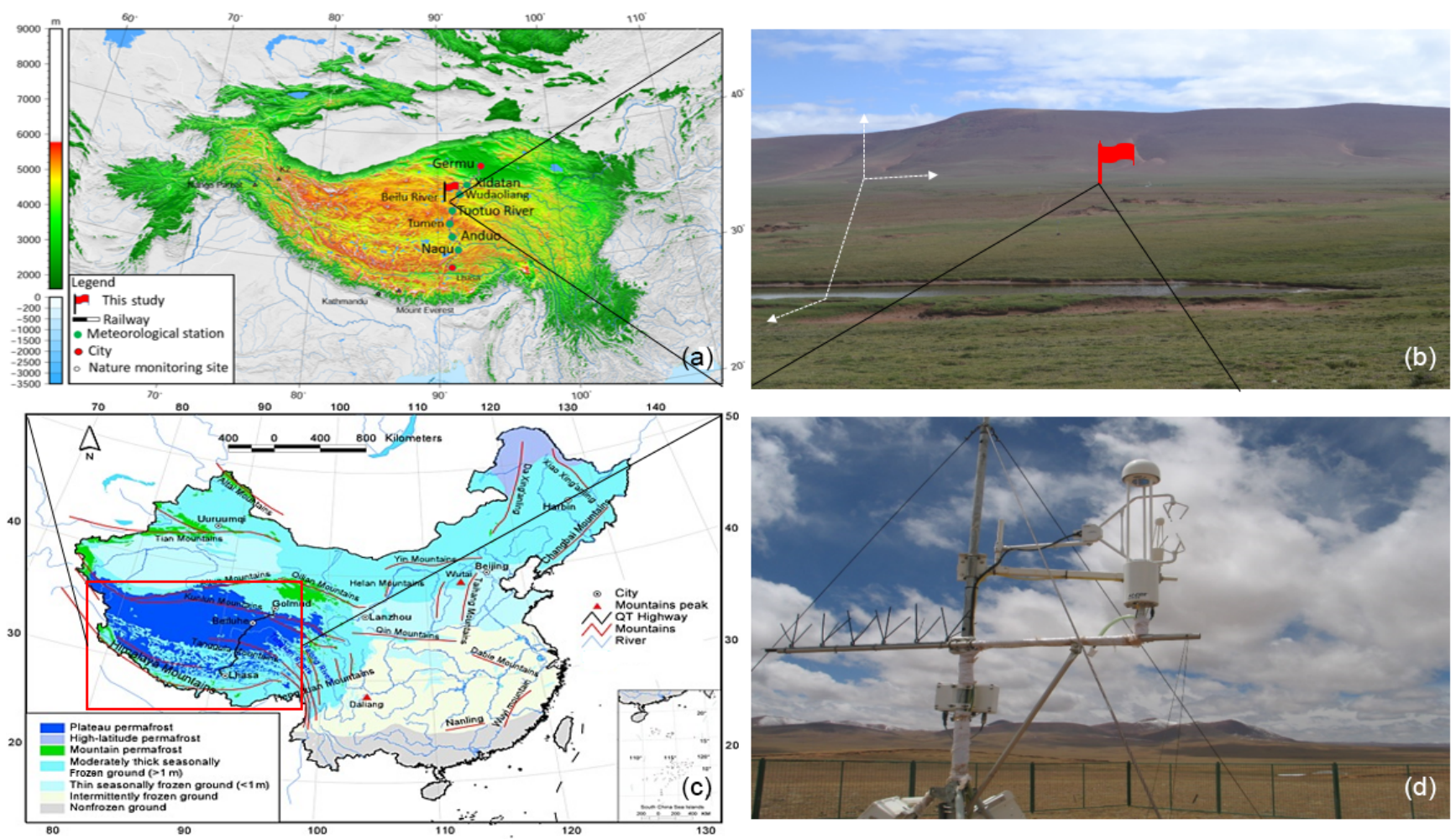

Figure 1. Geographic location of the study site. (a) Map of China's permafrost distribution, and the red box marks the approximate location of the Qinghai-Tibet Plateau. (b) The study site location and meteorological stations along the Qinghai-Tibet railway. (c) Photo showing the study site's topography and physiognomy. The small red flag in (c) is the eddy covariance tower location. (d) Close-up shot of the LI7700 for methane measurement. Map boundary and location are approximate. Geographic features and the names do not imply any official endorsement or recognition.

Table 1. Soil characteristics at the eddy covariance flux study site.

\begin{tabular}{llrrccccc}
\hline $\begin{array}{l}\text { Soil depth } \\
\mathrm{cm}\end{array}$ & Soil type & $\begin{array}{r}\text { Gravel content } \\
\mathrm{g} \mathrm{kg}^{-1}\end{array}$ & $\begin{array}{r}\text { SOC } \\
\mathrm{g} \mathrm{kg}^{-1}\end{array}$ & $\begin{array}{r}\text { Microbial numbers } \\
\times 10^{4}\end{array}$ & $\mathrm{pH}$ & $\begin{array}{c}\text { DBD } \\
\mathrm{g} \mathrm{cm}^{-3}\end{array}$ & $\begin{array}{c}\text { SWC } \\
\%\end{array}$ & $\begin{array}{c}\text { Total N } \\
\times 10^{3} \mathrm{mg} \mathrm{kg}^{-1}\end{array}$ \\
\hline $0-20$ & Clay & 22.3 & 2.8 & 3.44 & 8.7 & 1.75 & 18.26 & 0.87 \\
$20-50$ & Silty clay & 12.6 & 1.7 & 3.82 & 8.4 & 1.73 & 11.52 & 1.02 \\
$50-120$ & Silt and fine sand & 3.4 & 1.3 & 3.67 & 8.4 & 1.72 & 12.57 & 1.18 \\
$120-160$ & Silt and fine sand & 2.8 & 26.4 & 5.44 & 5.1 & 1.68 & 24.69 & 2.46 \\
$160-200$ & Silt and fine sand & 1.6 & 13.6 & 4.39 & 6.8 & 1.68 & 22.45 & 2.03 \\
\hline
\end{tabular}

Note gravel content diameter $\geq 0.5 \mathrm{~cm}$. SOC is soil organic content, DBD is dry bulk density, SWC is soil water content, and Total N is total nitrogen content.

generator measurements for LI-7500A analyzers were performed regularly by the China Land-Atmosphere Coordinated Observation System (CLAROS). Up-and-down mirrors of LI-COR 7700 were cleaned regularly every 30 days to make sure the signal strength was stronger than 80 . All of these instruments were powered by solar panel and battery.

\subsection{Micrometeorological and soil measurements}

A wide range of meteorological variables were measured by a standard automatic meteorological tower $3 \mathrm{~m}$ above the ground and $5 \mathrm{~m}$ north of the EC tower. Net radiation $(\mathrm{Rn})$ and albedo were measured with a four-component radiometer (Rn; CNR-1, Kipp and Zonen, the Netherlands). Air temperature $\left(T_{\text {air }}\right)$, air relative humidity, and atmospheric pressure were measured with a temperature and humidity sensor (HMP45C, Vaisala Inc., Helsinki, Finland) in the meteorological tower. A rain gauge (TE525MM, Texas Electronics Inc., Dallas, TX, USA) was used to measure precipitation. Wind speed and direction were observed using a propeller anemometer placed on the top of the meteorological tower.

We also measured soil heat fluxes, soil temperature, and soil relative water content (SWC). In August 2010, we installed sensors for soil environment and surface energy ex- 
change monitoring $10 \mathrm{~m}$ apart from the EC tower. Two selfcalibrating soil heat flux (SHF) sensors (HFP01) were placed 5 and $15 \mathrm{~cm}$ below the ground. A group $\mathrm{pF}$ meter sensor (Geoprecision, Germany) was embedded in the soil under the meteorological tower to measure soil temperature $\left(T_{\text {soil }}\right)$ at 0 , $5,10,15,20,30,40,50,70,80,100,150,160$, and $200 \mathrm{~cm}$ of depth. The pF meter sensors also measured SWC at 10, 20, 40,80 , and $160 \mathrm{~cm}$ of depth.

All of the above environmental parameters were synchronously monitored with EC, and the data were recorded every $30 \mathrm{~min}$ by CR3000 (data logger, Campbell Scientific Ltd., Salt Lake City, UT, USA). The air temperature sensors, the humidity sensors, and the $\mathrm{pF}$ meter sensors were calibrated in the State Key Laboratory of Frozen Soil Engineering at the Chinese Academy of Sciences in order to ensure the measurement accuracy was within $\pm 0.05^{\circ} \mathrm{C}$ and $\pm 5 \%$.

We also sampled soil profiles for soil physical and chemical measurements with one $1 \mathrm{~m} \times 1 \mathrm{~m} \times 2 \mathrm{~m}$ pit $10 \mathrm{~m}$ from the EC tower in August 2010. Five profile samples were taken from the pit at depths of 0-20, 20-50, 50-120, 120-160, and $160-200 \mathrm{~cm}$. Sampling at each depth was repeated five times and the samples of the same depths were then well mixed. After that, the mixed soil sample of each depth was stored in aluminum boxes and carefully sealed to prevent gas exchanges with air. The clod method was used to investigate the field wet bulk density (weight of soil per unit volume; Cate and Nelson, 1971). The soil moisture content was calculated gravimetrically with the ratio of the mass of water present to the oven-dried $\left(60^{\circ} \mathrm{C}\right.$ for $\left.24 \mathrm{~h}\right)$ weight of the soil sample. The soil organic carbon (SOC) content of the air-dried soil samples was analyzed using the wet combustion method, Walkley-Black modified acid dichromate digestion, $\mathrm{FeSO}_{4}$ titration, and an automatic titrator. Total nitrogen (TN) and $\mathrm{pH}$ were measured using standard soil test procedures from the Chinese Ecosystem Research Network.

To understand the potential effect of soil thawing and freezing dynamics on $\mathrm{CH}_{4}$ fluxes, we also reconstructed and verified semi-monthly data of soil ALT. Following Muller's original definition, ALT is the maximum thaw depth in the late autumn using a linear interpolation of $T_{\text {soil }}$ profiles between two neighboring points above and below the $0{ }^{\circ} \mathrm{C}$ isotherm (Muller, 1947). We used records of the soil thawing thickness measured with a self-made geological probe to verify the ALT data semi-monthly. More information about the measurement procedure was previously described by $\mathrm{Wu}$ and Zhang (2010a).

\subsection{Microbial activity}

To understand how soil microbial activity may have impacted the $\mathrm{CH}_{4}$ fluxes, we sampled $100 \mathrm{~g}$ of soils for soil microbial activity measurements. These soils were obtained using a soil sample drill device $(\varnothing=0.03 \mathrm{~m})$, with depths of $0-25 \mathrm{~cm}$ taken every 5 days within $100 \mathrm{~m}$ of the EC tower. The sampled soil was fully mixed and divided into two equal parts. Each part was then stored in sterilized aluminum boxes and then placed in liquid nitrogen before sending to the lab for microbe RNA extraction. We then used a realtime polymerase chain reaction (PCR) method to genetically test methanotrophic-archaeal methanogens, and the procedure was repeated three times for each sample. By setting the maximum methanotrophic-archaeal methanogen gene expression cyclic number as 1 , we calculated the variety coefficient of methanotrophic and archaeal methanogen gene expressions ( $\Delta \mathrm{I}$ and $\Delta \mathrm{II}$, respectively; \%) with Eq. (1):

$\Delta_{i}=x_{i} / X_{\operatorname{Max}}$

$\Delta_{i}$ is for the $i$ th methanotrophic-archaeal methanogen gene expression; $x_{i}$ is the methanotrophic-archaeal methanogen gene expression cyclic number of the $i$ th time; $x_{\text {Max }}$ is the maximum methanotrophic-archaeal methanogen gene expression cyclic number of the soil group from 2012 to 2016.

\subsection{EC data processing and data filtering}

Data collected from 1 January 2012 to 31 December 2016 were used in this study. Before processing, we removed data that were recorded at the time of precipitation events or with a LI-7700 signal strength under 85. We first processed the raw data in EddyPro (version 6.2.0, Li-cor, Lincoln, NE, USA). We adopted standardized procedures recommended in Lee et al. (2006) to process half-hourly flux raw measurements to ensure their quality.

1. Data were processed through statistical analysis in EddyPro including spike removal (accepted spikes $<5 \%$ and replaced spikes with linear interpolation), amplitude resolution (range of variation: $7.0 \sigma$; number of bins: 100; accepted empty bins: $70 \%$ ), dropouts (percentile defining extreme bins: 10; accepted central dropouts: 10\%; accepted extreme dropouts: 6\%), absolute limits $\left(-30 \mathrm{~ms}^{-1}<U<30 \mathrm{~ms}^{-1},-5 \mathrm{~ms}^{-1}<W<5 \mathrm{~ms}^{-1}\right.$, $-40^{\circ} \mathrm{C}<T_{\text {soil }}<40^{\circ} \mathrm{C} ; \quad 200 \mu \mathrm{mol} \mathrm{mol}^{-1}<$ $\mathrm{CO}_{2}<500 \mu \mathrm{mol} \mathrm{mol}^{-1}, \quad 0 \mu \mathrm{mol} \mathrm{mol}^{-1}<\mathrm{H}_{2} \mathrm{O}<$ $\left.40 \mu \mathrm{mol} \mathrm{mol}^{-1}, 0.17 \mu \mathrm{mol}<\mathrm{CH}_{4}<1000 \mu \mathrm{mol}\right)$, skewness and kurtosis $(-2.0<$ skewness lower limit $<$ $-1.0, \quad 1.0<$ skewness upper limit $<2.0 ; \quad 1.0<$ kurtosis lower limit $<2.0,5.0<$ kurtosis upper limit $<$ 8.0), discontinuities (hard-flag threshold: $U=4.0$, $W=2.0, \quad T_{\text {soil }}=4.0, \quad \mathrm{CO}_{2}=40, \quad \mathrm{CH}_{4}=40, \quad$ and $\mathrm{H}_{2} \mathrm{O}=3.26$; soft-flag threshold: $U=2.7, W=1.3$, $T_{\text {soil }}=2.7, \mathrm{CO}_{2}=27, \mathrm{CH}_{4}=30$, and $\mathrm{H}_{2} \mathrm{O}=2.2$ ), angle of attack (minimum angle of attack $=-30$; maximum angle attack $=30$; accepted number of outliers $=10 \%$ ), and steadiness of horizontal wind (accepted wind relative instationarity $=0.5$ ) (Vickers and Mahrt, 1997; Mauder et al., 2013).

2. The data were then corrected using atmosphere physical calculations expressed by axis rotations of tilt correction 
(double rotation), time lags compensation (covariance maximization), and compensating density fluctuations of Webb-Pearman-Leuning (Webb et al., 1980). When $\mathrm{CO}_{2}$ and $\mathrm{H}_{2} \mathrm{O}$ molar densities are measured with the Li-cor $7500 / \mathrm{Li}$-cor $7500 \mathrm{~A}$ in cold environments (low temperatures below $-10^{\circ} \mathrm{C}$ ), a correction should be applied to account for the additional instrument-related sensible heat flux due to instrument surface heatingcooling. Thus, we implemented the correction according to Burba et al. (2008), which involves calculating a corrected sensible heat flux $\left(H^{\prime}\right)$ by adding estimated sensible heat fluxes from key instrument surface elements, including the bottom window $\left(H_{\text {bot }}\right)$, top window $\left(H_{\text {top }}\right)$, and spar $\left(H_{\text {spar }}\right)$, to the ambient sensible heat flux $(H)$ :

$H^{\prime}=H+H_{\mathrm{bot}}+H_{\mathrm{top}}+0.15 \cdot H_{\mathrm{spar}}$.

3. Quality assurance (QA) and quality control (QC) were ensured through spectral analysis and correction analysis in EddyPro. Spectra and co-spectra calculations used power-of-two samples to speed up the fast Fourier transform (FFT) algorithm. Here we checked the "Filter (co-)spectra according to Vickers and Mahrt (1997) test results" box in EddyPro, which would then disregard EC flux time series that would likely create artifacts in spectral and co-spectral shapes. We also used the Foken and Wichura (1996) and Mauder et al. (2013) micrometeorological quality tests embedded in EddyPro to filter low-quality EC time series data. Low-frequencyrange spectral correction was performed considering high-pass filtering effects. High-frequency-range spectral correction was carried out considering low-pass filtering effects (Moncrieff et al., 2004).

4. We chose values of "0", "1", and "2" to flag the processed flux data into three quality classes in EddyPro. The combined flag attains the value 0 for the bestquality fluxes, 1 for fluxes suitable for general analysis, such as annual budgets, and 2 for fluxes that should be discarded from the dataset of results. For our dataset, approximately $67 \%$ of the data fell into Class $0,12 \%$ in Class 1, and $21 \%$ in Class 2.

5. Our analysis indicated that, under average meteorological conditions, $80 \%$ of the flux (footprint) came from an area within $175 \mathrm{~m}$ of the EC tower.

In addition, we also adopted the method in Burba et al. (2008) to adjust the half-hour flux data to avoid apparent measurement errors. In doing this, we rejected half-hour flux data that fell into one of the following situations: (1) incomplete half-hour measurements, (2) measurements under rain impacts, (3) nighttime measurements under stable atmospheric conditions (friction velocity $U^{*}<0.1 \mathrm{~m} \mathrm{~s}^{-1}$ ), and
(4) abnormal values detected by a three-dimensional ultrasonic anemometer. This screening resulted in the rejection of about $20.7 \%$ of all the flux data.

After the above data QC, there was a $28.7 \%$ data gap for $\mathrm{CH}_{4}$ fluxes over the entire period. These data gaps were then filled according to the method described in the literature (Falge et al., 2001; Papale et al., 2006). We used a linear interpolation to fill the gaps if they were less than $2 \mathrm{~h}$, a method described in Falge et al. (2001) to fill gaps greater than $2 \mathrm{~h}$ but less than 1 day, and an artificial neural network approach as described in Papale et al. (2006) and Dengel et al. (2013) to fill gaps greater than 1 day.

The quality of the dataset was evaluated using the equation of energy closure:

$\mathrm{EBR}=\sum(H+\lambda E) / \sum\left(R_{\mathrm{n}}-G-S\right)$,

where the EBR is surface energy balance ratio, $H$ is heat flux, $\lambda E$ is latent heat, $R_{\mathrm{n}}$ is net radiation, $G$ is SHF, and $S$ is heat storage of the vegetation canopy. As vegetation coverage at this research site is sparse, $S$ is ignored. From 2012 to 2016, the average EBR value at the Beilu'he EC site was about 0.675 , falling within the range of 0.34 to 1.69 in an analysis of energy balance closure for global FLUXNET sites (Wilson et al., 2002).

We analyzed two different major sources of $\mathrm{CH}_{4}$ flux gapfilling uncertainty. The first kind of uncertainty came from the $U^{*}$ threshold estimate. Following Burba et al. (2008), we excluded the probably false low $\mathrm{CH}_{4}$ flux at low $U^{*}$. However, it was difficult to determine the value for the $U^{*}$ threshold. For instance, when choosing a lower $U^{*}$ threshold, the associated lower flux would contribute to the gap filling and the annual gross (Loescher, et al., 2006). Here we used the variance from $5 \%$ to $95 \%$ of the bootstrapped values to provide an estimate on the uncertainties caused by different $U^{*}$ thresholds. The second uncertainty source was due to insufficient power supply. In this research, all instrument power was supplied by solar panels. Extended periods of rainy, cloudy, and snowy weather would cause the instrument to stop working due to an insufficient power supply. When we used the gap-filling method mentioned above, it would cause the $\mathrm{CH}_{4}$ flux to deviate from the true value. To our knowledge, the $\mathrm{CH}_{4}$ flux data were largely uncertain under rainy conditions.

\subsection{New classification system of the four seasons based on microbial activity classification}

We redefined the four seasons of spring, summer, autumn, and winter based on the microbial activity parameters of the new seasons (Fig. 2), ALT variability coefficients (ALT variability coefficient $=\left(\mathrm{ALT}_{i+1}-\mathrm{ALT}_{i}\right) / \mathrm{ALT}_{\mathrm{Max}}$, where $\mathrm{ALT}_{\text {Max }}$ is the maximum of ALT per year), and $T_{\text {soil }}$. Below, we describe the start date of each season (the end date of a season is the day immediately before the start of the next season). 

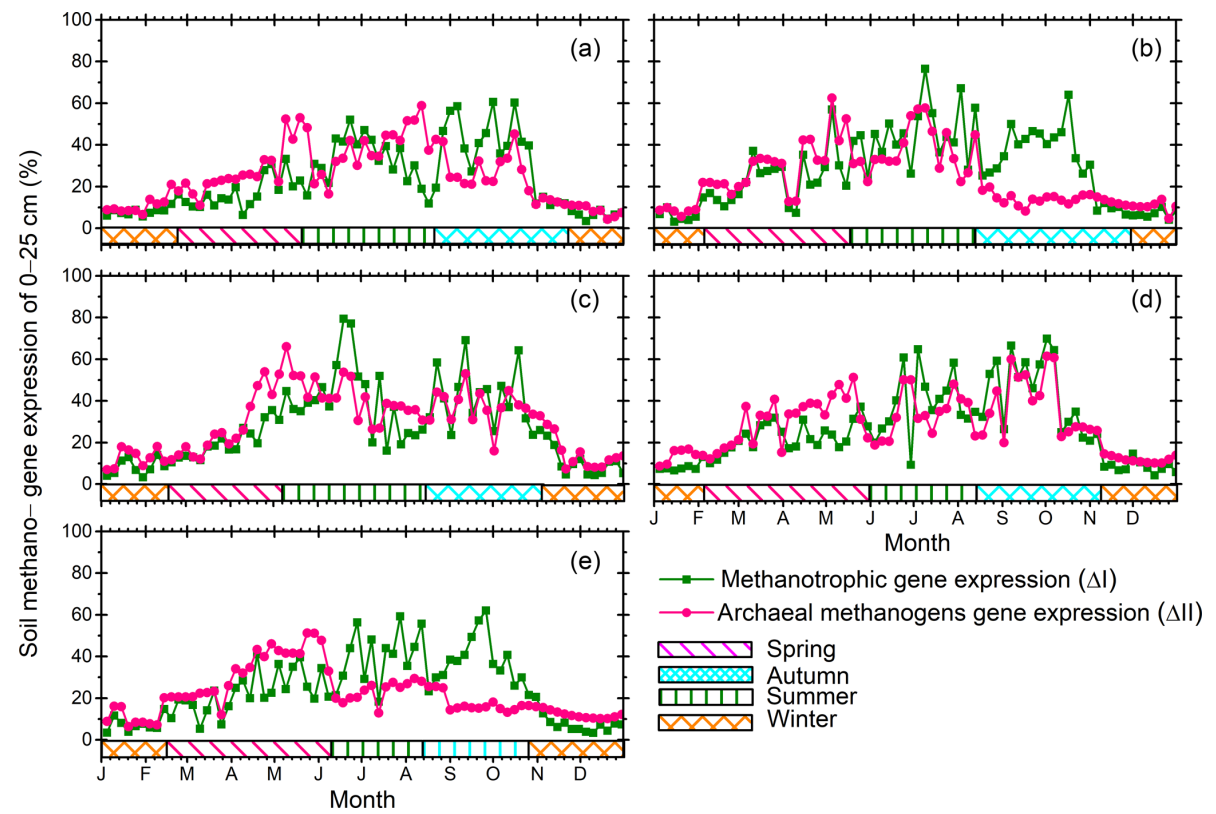

Figure 2. Annual patterns of soil methanogen gene expression of 0-25 cm soil depth for the years (a) 2012, (b) 2013, (c) 2014, (d) 2015, and (e) 2016 .

Spring starts at the first day of two consecutive observation periods fulfilling both (1) $(\Delta \mathrm{II}+\Delta \mathrm{I}) / 2 \geq 15 \%$ and (2) the ALT variability coefficient $\geq 0.05$.

Summer starts on the first day of two consecutive observation periods when (1) $(\Delta \mathrm{II}+\Delta \mathrm{I}) / 2 \geq 45 \%$, (2) the ALT variability coefficient is $\geq 0.35$, and (3) 5 successive days have a $T_{\text {soil }}$ at $40 \mathrm{~cm}$ of soil depth $\geq 0{ }^{\circ} \mathrm{C}$.

Autumn starts on the first day of two consecutive observation periods when (1) $(\Delta \mathrm{II}+\Delta \mathrm{I}) / 2 \geq 55 \%$, (2) the ALT variability coefficient is $\geq 0.60$, and (3) 5 successive days have a $T_{\text {soil }}$ of $10 \mathrm{~cm}<5^{\circ} \mathrm{C}$.

Winter starts on the first day of two consecutive observation periods that have (1) $(\Delta \mathrm{II}+\Delta \mathrm{I}) / 2<15 \%$ and (2) the ALT variability coefficient $<0.05$.

To test the robustness of our new seasonal division method in our methane cycle analysis, we compared empirical $\mathrm{CH}_{4}$ flux estimates using different season definitions (Table 2). In addition to our new method that was based on top soil microbe activity, $T_{\text {soil }}$ of $0-40 \mathrm{~cm}$, and permafrost active layer variability (hereafter referred to as SMT), we also used three conventional methods, based on (i) vegetation cover and temperature change (VCT), (ii) Julian months (JMC), and (iii) vegetation phenology change (VPC). The VCT method splits a year into a plant growing season and a nongrowing season; the JMC method assumes May to October as a plant growing season, and November to the following April as a nongrowing season; and the VPC method defines a plant growing season as the period between the time when all dominant grass species (Carex moorcroftii Falc. ex Boott, Kobresia tibetica Maxim, Androsace tanggulashanensis, Rhodiola tibetica) germinate and when they all senesce.

\subsection{Statistical analyses}

To understand the connections between $\mathrm{CH}_{4}$ fluxes and associated environmental factors, we performed a series of statistical analyses, including correlation, principal component analysis (PCA), and linear regression analyses, in IBM SPSS (IBM SPSS Statistics 24; IBM, Armonk, NY, USA). Specifically, we used bivariate correlation to examine pairwise relationships between environmental factors and $\mathrm{CH}_{4}$ fluxes. We also used PCA and linear regressions to explore the sensitivity of $\mathrm{CH}_{4}$ fluxes to simultaneous environmental fluctuations in wind speed, $T_{\text {air }}$, air relative humidity, $\mathrm{Rn}$, vapor pressure deficit (VPD), albedo, SHF, SWC, and $T_{\text {soil }}$. Before performing PCA and linear regressions, the entire dataset was examined for outliers (Cook's distance, $<0.002$ ), homogeneity of variance (Levene's test, $p<0.05$ ), normality (KolmogorovSmirnov test; smooth line for histogram of Studentized residuals), collinearity (variance inflation factor, $0<\mathrm{VIF}<10$ ), potential interactions ( $t$ test, $p<0.05)$, and independence of observations ( $t$ test, $p<0.05$ ).

We performed structural equation modeling (SEM) to evaluate the effects of environmental variables on $\mathrm{CH}_{4}$ fluxes for different seasons. SEM is a widely used multivariate statistical tool that incorporates factor analysis, path analysis, and maximum likelihood analysis. This method uses a priori knowledge of the relationships among focus variables to verify the validity of hypotheses. Here we performed SEM analyses with AMOS 21.0 (Amos Development Corporation, Chicago, IL, USA). All data are presented as mean values with standard deviations. 
Table 2. Measurements of four seasons from 2012 to 2016.

\begin{tabular}{|c|c|c|c|c|c|c|}
\hline & $\begin{array}{l}\text { Spring period; } \\
\text { total days } \\
\text { days }\end{array}$ & $\begin{array}{l}\text { Summer period; } \\
\text { total days } \\
\text { days }\end{array}$ & $\begin{array}{l}\text { Autumn period; } \\
\text { total days } \\
\text { days }\end{array}$ & $\begin{array}{l}\text { Winter period; } \\
\text { total days } \\
\text { days }\end{array}$ & $\begin{array}{l}\text { Plant growing season } \\
\text { period; total days } \\
\text { days }\end{array}$ & $\begin{array}{l}\text { Plant nongrowing season } \\
\text { period; total days } \\
\text { days }\end{array}$ \\
\hline 2012 & $50-142 ; 93$ & $143-229 ; 87$ & $230-323 ; 94$ & $1-49,324-366 ; 92$ & $\begin{array}{l}139-286 ; 148^{\mathrm{a}} \\
122-305 ; 184^{\mathrm{b}} \\
143-290 ; 148^{\mathrm{c}}\end{array}$ & $\begin{array}{l}1-138,287-366 ; 218^{\mathrm{a}} \\
1-121,306-366 ; 182^{\mathrm{b}} \\
1-142,291-366 ; 218^{\mathrm{c}}\end{array}$ \\
\hline 2013 & $36-137 ; 102$ & $138-224 ; 87$ & $225-334 ; 110$ & $1-35,335-365 ; 66$ & $\begin{array}{l}139-287 ; 149^{\mathrm{a}} \\
121-304 ; 184^{\mathrm{b}} \\
127-297 ; 171^{\mathrm{c}}\end{array}$ & $\begin{array}{l}1-138,288-365 ; 216^{a} \\
1-120,305-365 ; 181^{b} \\
1-126,298-365 ; 194^{c}\end{array}$ \\
\hline 2014 & $49-127 ; 79$ & $128-228 ; 101$ & $229-309 ; 81$ & $1-48,310-365 ; 104$ & $\begin{array}{l}137-288 ; 152^{\mathrm{a}} \\
121-304 ; 184^{\mathrm{b}} \\
142-294 ; 153^{\mathrm{c}}\end{array}$ & $\begin{array}{l}1-136,289-365 ; 213^{a} \\
1-120,305-365 ; 181^{b} \\
1-141,295-365 ; 212^{c}\end{array}$ \\
\hline 2015 & $36-150 ; 115$ & $151-224 ; 74$ & $225-312 ; 88$ & $1-35,313-365 ; 88$ & $\begin{array}{l}145-288 ; 144^{\mathrm{a}} \\
121-304 ; 184^{\mathrm{b}} \\
136-295 ; 160^{\mathrm{c}}\end{array}$ & $\begin{array}{l}1-144,289-365 ; 221^{a} \\
1-120,305-365 ; 181^{b} \\
1-135,296-365 ; 205^{c}\end{array}$ \\
\hline 2016 & $47-161 ; 115$ & $162-225 ; 64$ & $226-299 ; 74$ & $1-46,300-366 ; 113$ & $\begin{array}{l}141-287 ; 147^{\mathrm{a}} \\
122-305 ; 183^{\mathrm{b}} \\
140-296 ; 157^{\mathrm{c}}\end{array}$ & $\begin{array}{l}1-140,288-366 ; 219^{a} \\
1-120,305-366 ; 182^{b} \\
1-139,297-366 ; 209^{c}\end{array}$ \\
\hline
\end{tabular}

${ }^{a}$ Based on vegetation cover and temperature change (VCT) (Lund et al., 2010; Tang et al., 2013; Song et al., 2015). ${ }^{\mathrm{b}}$ Based on Julian months (JMC) (Wei et al., 2015a). ${ }^{\mathrm{c}}$ Based on vegetation phenology change (VPC). Spring, summer, autumn, and winter are based on parameters of microbial activities, ALT variety coefficient, and $T_{\text {soil }}$ (SMT).

\section{Results}

\subsection{Meteorological conditions}

We first reported the statistics of the meteorological conditions at the Beilu'he permafrost weather station between 2012 and 2016. Mean annual $T_{\text {air }}$ was $-4.5^{\circ}$ (Fig. S1 in the Supplement), with minimum and maximum mean diel temperatures of $-21.6^{\circ}$ (12 January 2012) and $13.8^{\circ}$ (28 July 2015), respectively. Average net radiation was $82.8 \mathrm{~W} \mathrm{~m}^{-2}$, with the maximum in August $\left(136.2 \mathrm{~W} \mathrm{~m}^{-2}\right.$; Fig. S2). The average VPD was about 0.3 , with maximum and minimum values of 0.98 , and 0.02 , respectively (Fig. S3). Mean annual precipitation was $335.4 \mathrm{~mm}$ (Fig. 3), which was primarily based on rain and snowfall (only occupied $7 \%$ ). Maximum and minimum precipitation was recorded in $2013(488.3 \mathrm{~mm})$ and $2015(310.0 \mathrm{~mm})$, respectively. The majority of precipitation, approximately $92 \%$, hereby occurred in the summer. During the winter, precipitation was rare, with mean values around $6.7 \mathrm{~mm}$. Spring was another important rainfall period in addition to summer, with mean precipitation being about $37.5 \mathrm{~mm}$, or $8 \sim 17 \%$ of the total.

The Beilu'he site is windy during most of the year (Fig. S4). Its annual average speed was $4.4 \mathrm{~m} \mathrm{~s}^{-1}$ from 2012 to 2016, while the principal direction of the strongest winds was from the southwest. Late autumn, winter, and early spring drought brought increased risks of dust-blowing days, with an average of 122 days within a year. Its summer average wind speed was about $3.30 \mathrm{~m} \mathrm{~s}^{-1}$, predominantly driven by the southwest wind.
The SWC and $T_{\text {soil }}$ variability from 2012 to 2016 at the field site are summarized in Figs. S5 and S6, respectively. Mean SWC of depths of $10,20,40,80$, and $160 \mathrm{~cm}$ were $14 \%, 9 \%, 8 \%, 14 \%$, and $19 \%$. $T_{\text {soil }}$ of depths $<100 \mathrm{~cm}$ corresponded with the $T_{\text {air }}$ changes, but showed stronger differences at depths $>100 \mathrm{~cm}$. The $T_{\text {soil }}$ at $200 \mathrm{~cm}$ of depth showed a remarkable difference from that of other layers. The reason could be the occurrence of peat in this layer, and that, during winter, the peat layer was not completely frozen. Figure S7 shows SHF half-hour and diel-scale variability of 5 and $15 \mathrm{~cm}$ in depth. The annual mean value of SHF at 5 and $15 \mathrm{~cm}$ of depth is 7.6 and $6.8 \mathrm{~W} \mathrm{~m}^{-2}$, respectively.

Finally, Fig. S8 shows the site's average soil freezing and thawing dynamics observed from January 2012 to December 2016. The average ALT is $4.4 \mathrm{~m}$ from 2012 to 2016 . At $40 \mathrm{~cm}$ of depth the duration of the active layer ranged from 174 to 188 days, with an average variation of up to 14 days.

\subsection{Annual, seasonal, and diel variabilities in methane fluxes}

Our results indicated that the Beilu'he site was a $\mathrm{CH}_{4}$ sink, with an annual mean strength of $-0.86 \pm 0.23 \mathrm{~g} \mathrm{CH}_{4}$ $\mathrm{C} \mathrm{m}^{-2}$ (95\% confidence interval; negative values mean $\mathrm{CH}_{4}$ sinks; positive values mean $\mathrm{CH}_{4}$ sources). The strength of the $\mathrm{CH}_{4}$ sink varies across different years from $-0.57 \pm$ $0.27 \mathrm{~g} \mathrm{CH}_{4}-\mathrm{C} \mathrm{m}^{-2} \mathrm{yr}^{-1}$ in 2015 to $-1.49 \pm 0.38 \mathrm{~g} \mathrm{CH}_{4}-$ $\mathrm{C} \mathrm{m}^{-2} \mathrm{yr}^{-1}$ in 2014 (Fig. 3). The amount of gene expression by methanogens and methanotrophs at $0-25 \mathrm{~cm}$ soils in March and November, for instance, was about $16.8 \%$ 


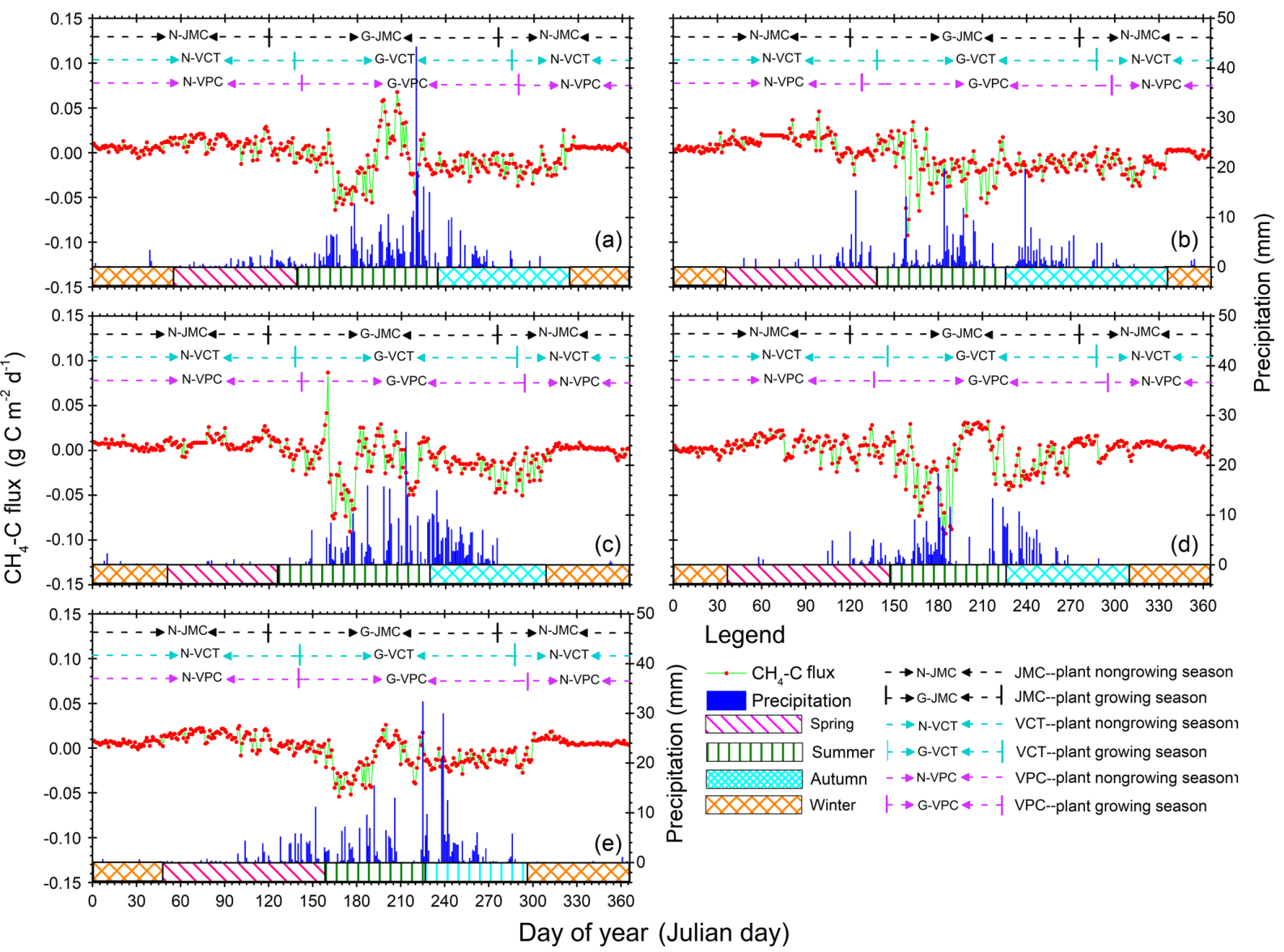

Figure 3. Annual patterns of diel methane $\left(\mathrm{CH}_{4}\right)$ flux and precipitation variations from 2012 to 2016 . Positive values indicate $\mathrm{CH}_{4}$ release and negative values indicate $\mathrm{CH}_{4}$ uptake by ecosystems. Red dots and light green lines are $\mathrm{CH}_{4}-\mathrm{C}$ flux variation, and the deep blue histograms show diel precipitation accumulation. Pink, olive, cyan, and orange blocks mean spring, summer, autumn, and winter seasons, respectively, according to our new method of SMT (see Sect. 2). Black, cyan, and pink dotted lines with bars separated the plant growing from nongrowing seasons and stand for seasons with the JMC, VCT, and VPC methods, respectively. Details about the JMC, VCT, and VPC methods can be found in Sect. 3.2.

and $35.6 \%$, respectively, suggesting strong microbial activities even during the cold and dry plant nongrowing season (Fig. 2).

We also clearly observed $\mathrm{CH}_{4}$ seasonal variations (Fig. S9) in both the number of $\mathrm{CH}_{4}$ exchanges and their diel cycles (Fig. 4). Across different seasons the footprint of the monitored $\mathrm{CH}_{4}$ flux changed following the change of the prevalent wind direction. In winter and spring, the major footprint was from east of the EC tower; while in summer and autumn, the major footprint was from west and north of the EC tower (Fig. S4).

In winter, the net $\mathrm{CH}_{4}$ flux at the Beilu'he site was an atmospheric source, with an average annual rate of $0.41 \pm$ $0.16 \mathrm{~g} \mathrm{CH}_{4}-\mathrm{C} \mathrm{m}^{-2} \mathrm{yr}^{-1}$ or $4.35 \pm 0.33 \mathrm{mg} \mathrm{CH}_{4}-\mathrm{C} \mathrm{m}^{-2} \mathrm{~d}^{-1}$ (Fig. S9a). It should also be noted that since the investigation started on 1 January 2012 and ended on 31 December 2016, the 2011-2012 and 2016-2017 winters were only about half of the regular length. The diel $\mathrm{CH}_{4}$ cycle of an average win- ter day was characterized by one single emission peak around 10:30-17:30 Beijing time (note all times hereafter are in Beijing time; Fig. 4a1-f1).

In spring, the Beilu'he site was a $\mathrm{CH}_{4}$ source of $0.90 \pm$ $0.37 \mathrm{~g} \mathrm{CH}_{4}-\mathrm{C} \mathrm{m}^{-2} \mathrm{yr}^{-1}$ (Fig. S9b), accounting for $53 \%$ of annual $\mathrm{CH}_{4}$ emissions, or $1.81 \pm 0.22 \mathrm{mg} \mathrm{CH}_{4}-\mathrm{C} \mathrm{m}^{-2} \mathrm{~d}^{-1}$. For a typical spring day (Fig. 4a2-e2), diel $\mathrm{CH}_{4}$ emission usually started at around 10:00-10:30, when the thin ice layer on the soil surface started to thaw. It then reached the peak at 12:30-13:30. The emission peak started to weaken at around 15:30-16:00 and reached around zero or even turned into a small sink after 20:00.

In summer, the Beilu'he site was a $\mathrm{CH}_{4}$ sink of $-0.99 \pm 0.18 \mathrm{~g} \mathrm{CH}_{4}-\mathrm{C} \mathrm{m}^{-2} \mathrm{yr}^{-1}$ (Fig. S9c), or $-13.28 \pm$ $0.38 \mathrm{mg} \mathrm{CH}_{4}-\mathrm{C} \mathrm{m}^{-2} \mathrm{~d}^{-1}$. The diel cycle of $\mathrm{CH}_{4}$ fluxes in summer was characterized by two absorption peaks and one small emission peak (Fig. 4a3-e3). With $T_{\text {air }}$ increasing after sunrise, the soil started to absorb atmospheric $\mathrm{CH}_{4}$ and this 

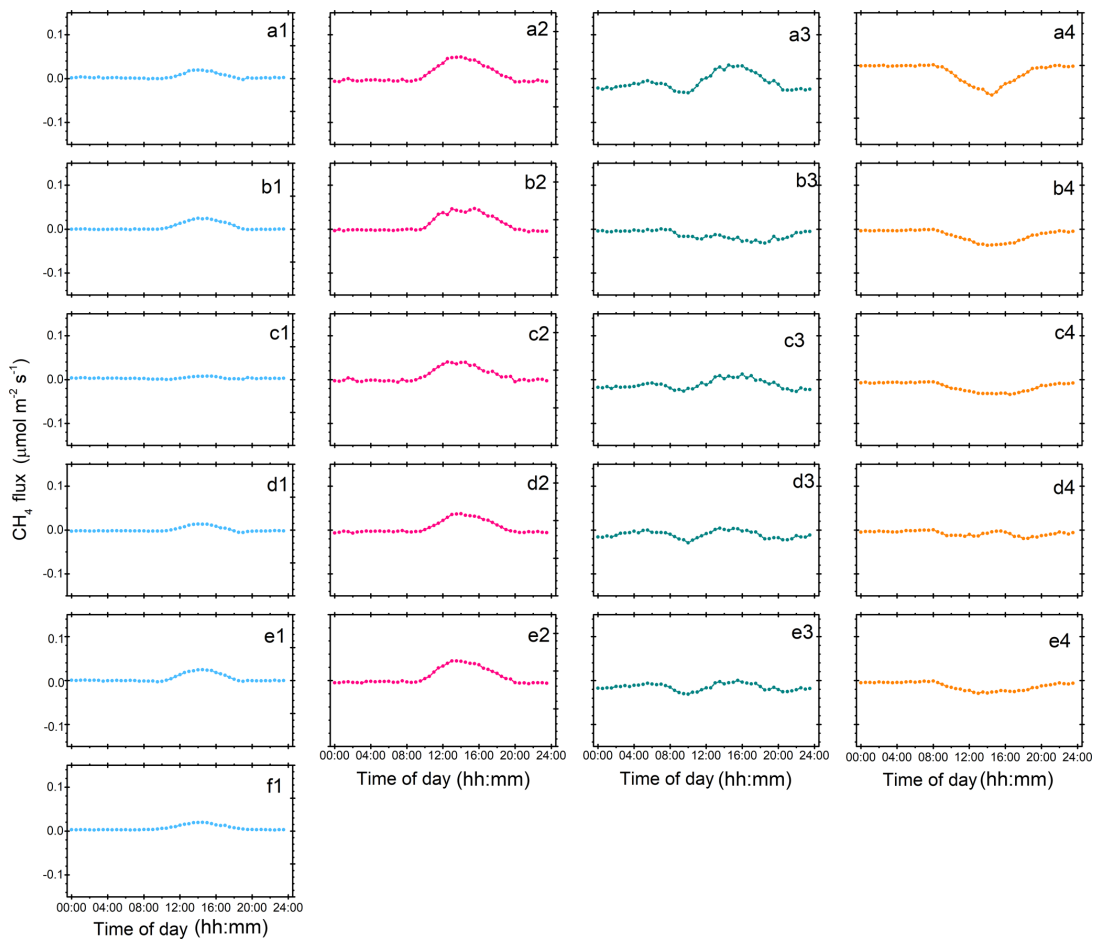

Time of day (hh:mm)

Figure 4. Diel $\mathrm{CH}_{4}$ fluxes from 2012 to 2016 for different seasons. Blue, pink, green and orange, represent winter, spring, summer, and autumn, respectively: (a1-a4) 2012, (b1-b4) 2013, (c1-c4) 2014, (d1-d4) 2015, (e1-e4), and (f1) 2016.

soil uptake process reached its first peak at around 09:3010:30. After that, the continuously increasing $T_{\text {air }}$ turned to suppress $\mathrm{CH}_{4}$ uptake and promote $\mathrm{CH}_{4}$ emissions, likely due to different temperature sensitivities of methanotrophic and methanogenic bacteria. At around 15:30-16:00, when $T_{\text {air }}$ reached the maximum (Fig. S1b), $\mathrm{CH}_{4}$ emission also reached its peak. The following temperature decrease in the late afternoon again reversed the $\mathrm{CH}_{4}$ uptake-emission process, and by sunset we observed another $\mathrm{CH}_{4}$ sink peak. The rate of $\mathrm{CH}_{4}$ sink then decreased again through the night with further decreasing temperature.

Autumn was another season with a net $\mathrm{CH}_{4}$ sink, with the season having the highest observed value for the site as a $\mathrm{CH}_{4}$ sink in 2013 (Fig. S9d). The $\mathrm{CH}_{4}$ sink in autumn varied between $-0.69 \pm 0.19 \mathrm{~g} \mathrm{CH}_{4}-\mathrm{C} \mathrm{m}^{-2}(2015)$ and $-1.59 \pm$ $0.33 \mathrm{~g} \mathrm{CH}_{4}-\mathrm{C} \mathrm{m}^{-2}$ (2013), with an average diel rate of $-1.19 \pm 0.48 \mathrm{~g} \mathrm{CH}_{4}-\mathrm{C} \mathrm{m}^{-2} \mathrm{yr}^{-1}$ or $-13.31 \pm 0.28 \mathrm{mg} \mathrm{CH}_{4}-$ $\mathrm{C} \mathrm{m}^{-2} \mathrm{~d}^{-1}$. The diel dynamics of autumn $\mathrm{CH}_{4}$ fluxes was like a letter "V", with a single sink peak during 13:30-15:30 (Fig. 4a4-e4).

\subsection{Response of methane fluxes to changes in environmental factors}

Diel fluxes of $\mathrm{CH}_{4}$ were correlated either positively or negatively with many biotic and abiotic environmental factors (Table 3). Positive factors include metagenomics of both methanotrophic $(r=0.52, p<0.01)$ and methanogens $(r=$
$0.49, p<0.01)$ at $0-25 \mathrm{~cm}$ soils, ALT $(r=0.43, p<0.01)$, and wind speed $(r=0.15, p<0.01)$. Important negative factors include VPD $(r=-0.26, p<0.01)$, SWC at all depths (varied $r$ values between -0.17 and $-0.26, p<0.01$ ), $T_{\text {air }}$ $(r=-0.11, p<0.01)$, and air pressure $(r=-0.15, p<$ $0.01)$. The correlation signal between $\mathrm{CH}_{4}$ fluxes and $T_{\text {soil }}$ changed with soil depths (varied $r$ values between -0.09 and $0.24, p<0.01)$. Furthermore, path analysis results showed that $T_{\text {soil }}$ values at 5 and $10 \mathrm{~cm}$ were the most important factors, which together contributed about $25 \%$ of the relative importance coefficient. Following these factors in importance were SWC at $80 \mathrm{~cm}(14 \%)$ and $20 \mathrm{~cm}(12 \%)$ and $T_{\text {soil }}$ at $20 \mathrm{~cm}(8 \%)$.

Further analyses suggested that dominant control factors of $\mathrm{CH}_{4}$ fluxes also changed among different seasons. In spring, $\mathrm{Rn}$ was the most important factor, with a relative importance coefficient near $60 \%$, followed by SHF at $5 \mathrm{~cm}$ $(9 \%)$ and SWC at $20 \mathrm{~cm}(6 \%)$. Table 4 shows the results of the PCA. In spring, $\mathrm{PC} 1$ explained $63 \%$ of the $\mathrm{CH}_{4}$ variations, which was positively correlated with $T_{\text {air }}$, VPD, Rn, SHF of $15 \mathrm{~cm}$, ALT, $\Delta \mathrm{I}, \mathrm{SWC}$ of $10-40 \mathrm{~cm}, T_{\text {soil }}$ of $0 \mathrm{~cm}$, $T_{\text {soil }}$ of $5-20 \mathrm{~cm}$, and $T_{\text {soil }}$ of $30-50 \mathrm{~cm}$ and negatively correlated with wind speed. The PC2 explained about $23 \%$ of $\mathrm{CH}_{4}$ flux variations. The first four principal components explained about $86 \%$ of the $\mathrm{CH}_{4}$ variations.

In summer, $\mathrm{CH}_{4}$ fluxes were mostly related with $T_{\text {soil }}$ at 100 and $200 \mathrm{~cm}$, with a relative importance coefficient of 
Table 3. Correlation coefficients between $\mathrm{CH}_{4}$ fluxes and environment factors on half-hour timescales.

\begin{tabular}{|c|c|c|c|c|c|c|c|c|c|c|}
\hline \multirow[t]{3}{*}{ Environment factors } & \multicolumn{10}{|c|}{$\mathrm{CH}_{4}$ Flux } \\
\hline & \multicolumn{2}{|c|}{ Spring } & \multicolumn{2}{|c|}{ Summer } & \multicolumn{2}{|c|}{ Autumn } & \multicolumn{2}{|c|}{ Winter } & \multicolumn{2}{|c|}{ 2012-2016 } \\
\hline & $r$ & $n$ & $r$ & $n$ & $r$ & $n$ & $r$ & $n$ & $r$ & $n$ \\
\hline$T_{\text {air }}$ & $0.25^{* *}$ & 24144 & $0.14^{* *}$ & 19818 & $-0.16^{* *}$ & 20959 & $0.32^{* *}$ & 22224 & $-0.11^{* *}$ & 87145 \\
\hline Wind speed & $0.31^{* *}$ & 24144 & $-0.04^{* *}$ & 19817 & $-0.20^{* *}$ & 20959 & $0.32^{* *}$ & 22224 & $0.15^{* *}$ & 87144 \\
\hline VPD & $-0.33^{* *}$ & 18624 & $-0.21^{* *}$ & 19263 & $-0.09^{* *}$ & 16737 & -0.21 & 18000 & $0.26^{* *}$ & 69624 \\
\hline $\mathrm{Rn}$ & $0.55^{* *}$ & 24143 & $0.09^{* *}$ & 19807 & $-0.33^{* *}$ & 20913 & $0.51^{* *}$ & 22224 & $0.09^{* *}$ & 87087 \\
\hline Albedo & $0.07^{* *}$ & 24144 & -0.01 & 19814 & $-0.08^{* *}$ & 20913 & $0.10^{* *}$ & 22224 & $0.02^{* *}$ & 87095 \\
\hline $\mathrm{SHF}$ of $5 \mathrm{~cm}$ & $0.46^{* *}$ & 24144 & $-0.08^{* *}$ & 19818 & $-0.23^{* *}$ & 20913 & $0.43^{* *}$ & 22224 & $0.09^{* *}$ & 87099 \\
\hline $\mathrm{SHF}$ of $15 \mathrm{~cm}$ & $0.36^{* *}$ & 24144 & $-0.15^{* *}$ & 19815 & $-0.23^{* *}$ & 20913 & $0.33^{* *}$ & 22224 & $0.08^{* *}$ & 87096 \\
\hline SWC of $10 \mathrm{~cm}$ & $-0.16^{* *}$ & 24144 & $-0.14^{* *}$ & 19818 & $-0.06^{* *}$ & 20959 & 0.00 & 22224 & $-0.25^{* *}$ & 87145 \\
\hline SWC of $20 \mathrm{~cm}$ & $-0.15^{* *}$ & 24144 & $-0.13^{* *}$ & 19816 & $-0.07^{* *}$ & 20959 & $0.11^{* *}$ & 22224 & $-0.24^{* *}$ & 87143 \\
\hline SWC of $40 \mathrm{~cm}$ & $-0.11^{* *}$ & 24144 & $-0.02^{* *}$ & 19818 & $0.07^{* *}$ & 20959 & $0.06^{* *}$ & 22224 & $-0.17^{* *}$ & 87145 \\
\hline SWC of $80 \mathrm{~cm}$ & & & $-0.13^{* *}$ & 19818 & $0.06^{* *}$ & 20959 & & & & \\
\hline $\mathrm{SWC}$ of $160 \mathrm{~cm}$ & & & $0.04^{* *}$ & 19818 & $-0.11^{* *}$ & 20959 & & & & \\
\hline Precipitation & & & -0.02 & 16748 & 0.01 & 17888 & & & & \\
\hline ALT & $0.73^{* *}$ & 23004 & $0.23^{* *}$ & 19823 & $0.73^{* *}$ & 21454 & & & $0.43^{* *}$ & 64281 \\
\hline$\Delta \mathrm{I}$ & $0.77^{* *}$ & 100 & $0.57^{* *}$ & 83 & $0.46^{* *}$ & 89 & 0.23 & 93 & $0.49^{* *}$ & 365 \\
\hline$\Delta \mathrm{II}$ & $0.31^{* *}$ & 100 & $0.66^{* *}$ & 83 & $0.78^{* *}$ & 89 & 0.19 & 93 & $0.52^{* *}$ & 365 \\
\hline$T_{\text {soil }}$ of $0 \mathrm{~cm}$ & $-0.06^{*}$ & 23004 & $0.13^{* *}$ & 19823 & $0.07^{* *}$ & 20366 & $0.13^{* *}$ & 21711 & $0.11^{* *}$ & 84904 \\
\hline$T_{\text {soil }}$ of $5 \mathrm{~cm}$ & $0.15^{* *}$ & 24144 & $0.15^{* *}$ & 19808 & $-0.13^{* *}$ & 21454 & $0.27^{* *}$ & 22224 & $0.24^{* *}$ & 87630 \\
\hline$T_{\text {soil }}$ of $10 \mathrm{~cm}$ & $-0.03^{* *}$ & 24144 & $0.12^{* *}$ & 19808 & $0.08^{* *}$ & 21454 & $0.16^{* *}$ & 22224 & $0.13^{* *}$ & 87630 \\
\hline$T_{\text {soil }}$ of $20 \mathrm{~cm}$ & $-0.14^{* *}$ & 24144 & $0.08^{* *}$ & 19808 & $0.02^{* *}$ & 21454 & $0.06^{* *}$ & 22224 & $-0.09^{* *}$ & 87630 \\
\hline$T_{\text {soil }}$ of $30 \mathrm{~cm}$ & $-0.13^{* *}$ & 23004 & $0.06^{* *}$ & 19823 & $-0.02^{* *}$ & 20366 & $0.07^{* *}$ & 21711 & $-0.08^{* *}$ & 84904 \\
\hline$T_{\text {soil }}$ of $40 \mathrm{~cm}$ & $0.14^{* *}$ & 24144 & $0.05^{* *}$ & 19808 & -0.01 & 21454 & $0.06^{* *}$ & 22224 & $0.11^{* *}$ & 87630 \\
\hline$T_{\text {soil }}$ of $50 \mathrm{~cm}$ & & & $0.04^{* *}$ & 19823 & $-0.05^{* *}$ & 20366 & & & & \\
\hline$T_{\text {soil }}$ of $70 \mathrm{~cm}$ & & & $0.07^{* *}$ & 19823 & $-0.05^{* *}$ & 20366 & & & & \\
\hline$T_{\text {soil }}$ of $80 \mathrm{~cm}$ & & & $0.05^{* *}$ & 19808 & $0.04^{* *}$ & 21454 & & & & \\
\hline$T_{\text {soil }}$ of $100 \mathrm{~cm}$ & & & $0.10^{* *}$ & 19823 & $-0.05^{* *}$ & 21454 & & & & \\
\hline$T_{\text {soil }}$ of $150 \mathrm{~cm}$ & & & $0.09^{* *}$ & 19823 & $-0.04^{* *}$ & 20366 & & & & \\
\hline$T_{\text {soil }}$ of $160 \mathrm{~cm}$ & & & $0.10^{* *}$ & 19808 & $0.01^{* *}$ & 21454 & & & & \\
\hline$T_{\text {soil }}$ of $200 \mathrm{~cm}$ & & & $0.02^{* *}$ & 19823 & $-0.02^{* *}$ & 20366 & & & & \\
\hline
\end{tabular}

Note ${ }^{* *}$ means $p<0.01$; means $p<0.05 ; r$ values are for the relationship between $\mathrm{CH}_{4}$ flux and environment factors. $T_{\text {air }}$ means air temperature of $3 \mathrm{~m}$ above the ground surface. VPD is vapor pressure deficit, Rn is net radiation, and SWC is soil water content. ALT is active layer thickness, which fitted through the depth of soil $0^{\circ}$ in Surfer 8.0, and the data are removed as meaningless in winter. $T_{\text {soil }}$ is the temperature of the soil. In spring and winter, precipitation data are too sparse for statistical analysis. $\Delta \mathrm{I}$ is the soil $0-25 \mathrm{~cm}$ archaeal methanogen gene expression, and $\Delta \mathrm{II}$ is the soil $0-25 \mathrm{~cm}$ methanotrophic gene expression. The coefficients $(r)$ between $\mathrm{CH}_{4}$ flux and $\Delta \mathrm{I}$ and $\Delta \mathrm{II}$ are obtained using the synchronous $\mathrm{CH}_{4}$ fluxes averaged for 5 days.

about $30.2 \%$ and $26.5 \%$, respectively. Other important environmental determinants of $\mathrm{CH}_{4}$ fluxes were $T_{\text {soil }}$ at $70 \mathrm{~cm}$ $(12.3 \%)$ and $T_{\text {soil }}$ at $0-20 \mathrm{~cm}(11.4 \%)$. The first four principal components explained about $88 \%$ of the $\mathrm{CH}_{4}$ variations (Table 4). $\mathrm{PC} 1$ explained $70 \%$ of the $\mathrm{CH}_{4}$ variations and was positively correlated with wind speed, $T_{\text {air }}$, VPD, SHF of $15 \mathrm{~cm}, \mathrm{ALT}, \Delta \mathrm{I}, \mathrm{SWC}$ of $50-160 \mathrm{~cm}$, precipitation, $T_{\text {soil }}$ of $0 \mathrm{~cm}, T_{\text {soil }}$ of 5-40 cm, $T_{\text {soil }}$ of $50-80 \mathrm{~cm}$, and $T_{\text {soil }}$ of $100-200 \mathrm{~cm}$, but negatively correlated with Rn and SWC of $10-40 \mathrm{~cm}$.

In autumn, Rn and $T_{\text {soil }}$ at $5-20 \mathrm{~cm}$ had the highest relative importance coefficients for explaining the $\mathrm{CH}_{4}$ flux variation. The first four principal components explained about $86 \%$ of the $\mathrm{CH}_{4}$ variations (Table 4). $\mathrm{PC} 1$ explained $69 \%$ of the $\mathrm{CH}_{4}$ variations and was positively correlated with $T_{\text {air }}$, VPD, Rn, SHF of $15 \mathrm{~cm}$, ALT, $\triangle \mathrm{I}$, SWC of $10-40 \mathrm{~cm}$, SWC of 50
$160 \mathrm{~cm}, T_{\text {soil }}$ of $0 \mathrm{~cm}, T_{\text {soil }}$ of $5-40 \mathrm{~cm}, T_{\text {soil }}$ of $50-80 \mathrm{~cm}$, and $T_{\text {soil }}$ of $100-200 \mathrm{~cm}$, but negatively correlated with wind speed.

During winter, $\mathrm{Rn}$ was again the most important factor (34\% relative importance coefficient), followed by $T_{\text {soil }}$ at 0 $40 \mathrm{~cm} \mathrm{(27 \%} \mathrm{in} \mathrm{total)} \mathrm{and} \mathrm{a} \mathrm{SHF} \mathrm{of} 15 \mathrm{~cm}$ (17\% in total), in determining $\mathrm{CH}_{4}$ fluxes. The first four principal components explained about $96 \%$ of the $\mathrm{CH}_{4}$ variations (Table 4). $\mathrm{PC} 1$ explained $75 \%$ of the $\mathrm{CH}_{4}$ variations and was positively correlated with wind speed, $T_{\text {air }}$, VPD, Rn, SHF of $15 \mathrm{~cm}, \Delta \mathrm{I}$, $T_{\text {soil }}$ of $0 \mathrm{~cm}$, and $T_{\text {soil }}$ of 5-20 cm. 
Table 4. Principal component analysis (PCA) of the environmental factors.

\begin{tabular}{|c|c|c|c|c|c|c|c|c|c|c|c|c|c|c|c|c|}
\hline \multirow[b]{2}{*}{ Component } & \multicolumn{4}{|c|}{ Spring } & \multicolumn{4}{|c|}{ Summer } & \multicolumn{4}{|c|}{ Autumn } & \multicolumn{4}{|c|}{ Winter } \\
\hline & $\mathrm{PC} 1$ & PC2 & PC3 & $\mathrm{PC} 4$ & $\mathrm{PC} 1$ & $\mathrm{PC} 2$ & PC3 & PC4 & $\mathrm{PC} 1$ & PC2 & PC3 & PC4 & $\mathrm{PC} 1$ & PC2 & PC3 & PC4 \\
\hline Wind speed & -0.03 & 0.51 & 0.65 & -0.46 & 0.02 & 0.37 & 0.38 & -0.13 & -0.04 & 0.44 & 0.59 & 0.67 & 0.27 & 0.45 & -0.11 & -0.27 \\
\hline$T_{\text {air }}$ & 0.38 & 0.29 & -0.05 & -0.11 & 0.42 & 0.22 & -0.03 & 0.02 & 0.36 & 0.21 & 0.08 & -0.06 & 0.48 & 0.12 & -0.02 & 0.01 \\
\hline VPD & 0.34 & -0.27 & 0.40 & 0.15 & 0.17 & 0.46 & -0.22 & 0.09 & 0.34 & -0.15 & 0.17 & -0.07 & 0.14 & -0.15 & 0.95 & -0.22 \\
\hline $\mathrm{Rn}$ & 0.16 & 0.49 & 0.00 & 0.76 & -0.01 & 0.07 & 0.58 & 0.11 & 0.12 & 0.54 & -0.43 & -0.07 & 0.26 & 0.47 & -0.01 & -0.49 \\
\hline SHF of $15 \mathrm{~cm}$ & 0.24 & 0.49 & -0.30 & -0.09 & 0.25 & 0.53 & -0.09 & 0.01 & 0.15 & 0.59 & -0.23 & -0.15 & 0.36 & 0.37 & 0.14 & 0.58 \\
\hline ALT & 0.22 & -0.40 & 0.40 & 0.27 & 0.32 & -0.53 & -0.05 & 0.02 & 0.29 & 0.49 & 0.70 & 0.25 & & & & \\
\hline$\Delta \mathrm{I}$ & 0.49 & -0.22 & 0.01 & -0.08 & 0.50 & -0.16 & 0.02 & -0.16 & 0.29 & 0.31 & 0.24 & -0.51 & 0.52 & 0.05 & 0.07 & -0.03 \\
\hline SWC of $10-20 \mathrm{~cm}$ & & & & & & & & & & & & & -0.31 & 0.45 & 0.22 & 0.47 \\
\hline SWC of $10-40 \mathrm{~cm}$ & 0.33 & -0.20 & 0.50 & 0.25 & -0.16 & 0.15 & -0.16 & 0.73 & 0.28 & -0.18 & -0.41 & 0.53 & & & & \\
\hline SWC of $50-160 \mathrm{~cm}$ & & & & & & 0.23 & -0.20 & -0.16 & 0.55 & 0.31 & -0.17 & -0.32 & 0.41 & & & \\
\hline Precipitation & & & & & & 0.03 & -0.04 & 0.63 & 0.35 & & & & & & & \\
\hline$T_{\text {soil }}$ of $0 \mathrm{~cm}$ & 0.43 & -0.07 & -0.20 & -0.27 & 0.43 & 0.08 & 0.08 & -0.07 & 0.37 & 0.07 & 0.19 & -0.16 & 0.43 & -0.35 & -0.15 & 0.09 \\
\hline$T_{\text {soil }}$ of $5-20 \mathrm{~cm}$ & 0.44 & -0.01 & -0.17 & -0.16 & & & & & & & & & 0.45 & -0.28 & 0.00 & 0.28 \\
\hline$T_{\text {soil }}$ of $5-40 \mathrm{~cm}$ & & & & & 0.46 & -0.05 & 0.04 & -0.03 & 0.38 & 0.02 & 0.18 & -0.17 & & & & \\
\hline$T_{\text {soil }}$ of $30-50 \mathrm{~cm}$ & 0.40 & -0.23 & -0.08 & -0.04 & & & & & & & & & & & & \\
\hline$T_{\text {soil }}$ of $50-80 \mathrm{~cm}$ & & & & & 0.37 & -0.36 & 0.00 & 0.01 & 0.37 & -0.11 & 0.19 & -0.14 & & & & \\
\hline$T_{\text {soil }}$ of $100-200 \mathrm{~cm}$ & & & & & 0.33 & -0.34 & 0.01 & -0.01 & 0.36 & -0.14 & 0.08 & 0.00 & & & & \\
\hline Percent of variance & 0.63 & 0.23 & 0.08 & 0.04 & 0.70 & 0.18 & 0.07 & 0.02 & 0.69 & 0.17 & 0.08 & 0.04 & 0.75 & 0.21 & 0.02 & 0.01 \\
\hline Cumulative & 0.63 & 0.86 & 0.94 & 0.98 & 0.70 & 0.88 & 0.95 & 0.97 & 0.69 & 0.86 & 0.94 & 0.98 & 0.75 & 0.96 & 0.98 & 0.99 \\
\hline
\end{tabular}

Note PC means principal component. Before PCA, SWC was divided into three parts, $10-20,10-40$, and $50-160 \mathrm{~cm}$, according to a collinearity test in four seasons. $T_{\text {soil }}$ was divided into six parts of $T_{\text {soil }}$ of $0 \mathrm{~cm}$, $T_{\text {soil }}$ of $5-20 \mathrm{~cm}, T_{\text {soil }}$ of $5-40 \mathrm{~cm}, T_{\text {soil }}$ of $30-50 \mathrm{~cm}, T_{\text {soil }}$ of $50-80 \mathrm{~cm}$, and $T_{\text {soil }}$ of $60-200 \mathrm{~cm}$ according to a collinearity test in different seasons.

\subsection{Empirical model comparison for different $\mathrm{CH}_{4}$ flux season classification system}

Lastly, we also compared how different season definitions, including the methods of SMT, VCT, JMC, and VPC, may have impacted the predictability of $\mathrm{CH}_{4}$ fluxes. We established empirical maximum likelihood models between all environmental factors and diel $\mathrm{CH}_{4}$ fluxes over each season, and then we compared modeled $\mathrm{CH}_{4}$ fluxes and field observations under those methods of different seasonal definitions (Fig. 5). We found that the agreement between modeled and observed $\mathrm{CH}_{4}$ fluxes, using the new SMT method, reached $R^{2}=0.28$, almost twice that of the VPC $\left(R^{2}=0.17\right)$ and VCT $\left(R^{2}=0.14\right)$ methods, and more than three times that of the JMC method $\left(R^{2}=0.08\right.$; Fig. 5). Hence, the comparison suggested that our new method could better model $\mathrm{CH}_{4}$ fluxes over a year. The use of the traditional plant growing season versus nongrowing season definitions may also underestimate or overestimate $\mathrm{CH}_{4}$ sinks or sources, especially when many studies assume $\mathrm{CH}_{4}$ is close to zero during the plant nongrowing season. Furthermore, the new SMT method accurately captures the impact of spring and autumn permafrost thawing-freezing cycles on $\mathrm{CH}_{4}$ fluxes and the different preferable environments for methanogens and methanotrophic bacteria during the summer season, while conventional methods do not.

\section{Discussion}

\subsection{Annual and season mean and diel variability}

Our results suggested that the alpine steppe ecosystem in Beilu'he was a $\mathrm{CH}_{4}$ sink of about $-0.86 \pm 0.23 \mathrm{~g} \mathrm{CH}_{4}$ -
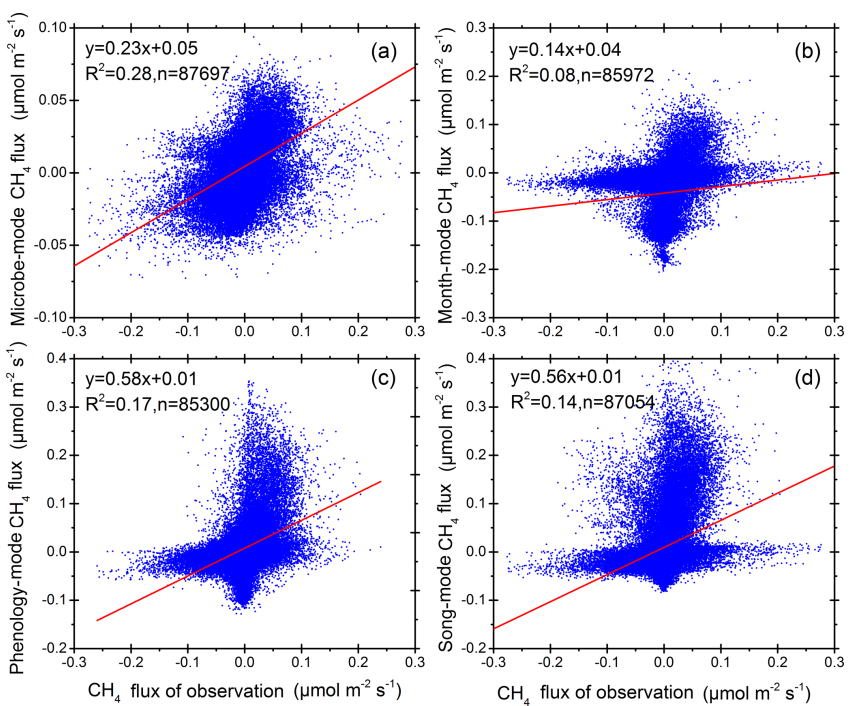

Figure 5. Regression comparison between observation and modeled methane fluxes with four different seasonal definitions and classification models. Panels (a), (b), (c), and (d) are for the SMT, JMC, VCT, and VPC methods, respectively.

$\mathrm{C} \mathrm{m}^{-2} \mathrm{yr}^{-1}$ during the study period of 2012-2016. This sink strength is larger than that of previous reports from other sites of the QTP (Cao et al., 2008; Wei et al., 2012; Li et al., 2012; Song et al., 2015; Chang and Shi, 2015) and many other high-latitude Arctic tundra ecosystems, like northeast Greenland (Jørgensen et al., 2015), western Siberia (Liebner et al., 2011), and Alaska (Whalen et al., 1992; Zhuang et al., 2004; Whalen, 2005). Different soil hydrothermal conditions, which previous studies have shown will greatly influence $\mathrm{CH}_{4}$ cycles in permafrost regions (Spahni et al., 2011; 
Kirschke et al., 2013), may partly explain the site difference in $\mathrm{CH}_{4}$ dynamics. For example, compared to the wet and often snow-covered high-latitude Arctic tundra ecosystems, there is no or little snow cover during the cold season in the QTP alpine steppes (Table S1 in the Supplement). During winter, the Beilu'he meteorological data show that the snow cover lasting $<33.7 \mathrm{~h}$, with a SWC of $0-40 \mathrm{~cm}$ within a footprint $<7.6 \%$ from 2012 to 2016 (Table S1), is far below high-latitude Arctic tundra ecosystems. Jansson and Taş (2014) pointed out that relatively dry soils could facilitate the oxidation of $\mathrm{CH}_{4}$ since the increased number of gaps between soil particles in dry soils enhances the diffusion of oxygen $\left(\mathrm{O}_{2}\right)$ and $\mathrm{CH}_{4}$ molecules and promotes aerobic respiration of soil microorganisms (Wang et al., 2014; Song et al., 2015). Meanwhile, unfrozen or capillary water found in cold season permafrost soils ensures sufficient soil moisture for microbial activities, even in relatively drier and cold soils (Panikov and Dedysh, 2000; Rivkina et al., 2004). In addition, many previous studies used static chambers in $\mathrm{CH}_{4}$ measurements and may not have included a plant nongrowing season (Wei et al., 2015a; Wang et al., 2014). Static chambers could underestimate $\mathrm{CH}_{4}$ uptake because of the additional chamber heating-induced $\mathrm{CH}_{4}$ emissions and frequent measurement gaps from overheating preventive shutdowns (Sturtevant et al., 2012).

We argued that seasonal freezing and thawing dynamics may be a key reason to explain the site's seasonal difference in $\mathrm{CH}_{4}$ dynamics. Freezing and thawing processes are typical characteristics of the QTP permafrost (Wang et al., 2008, 2000; Qin et al., 2016). Our work suggests that freezing and thawing dynamics have played a critical role in governing permafrost seasonal and diel $\mathrm{CH}_{4}$ cycling. For instance, while both spring and autumn are active seasons for the freeze-thaw dynamics of top soil layers and share many similarities, they have opposite $\mathrm{CH}_{4}$ processes and soils that emit $\mathrm{CH}_{4}$ during spring (Fig. S9b) but consume $\mathrm{CH}_{4}$ during autumn (Fig. S9d). We hypothesize that the difference in the freezing and thawing processes of the two seasons may have played a critical role in determining the direction of $\mathrm{CH}_{4}$ dynamics. In spring, the SWC of $10 \mathrm{~cm}$, of $20-40 \mathrm{~cm}$, of $80 \mathrm{~cm}$, and of $160 \mathrm{~cm}$ depth is $12.4 \%, 9.2 \%, 11.4 \%$, and $13.6 \%$, respectively (Table $\mathrm{S} 1$ ). The active soil layer thaws from top to bottom (Jin et al., 2000; Cao et al., 2017), and the permafrost table is very shallow (about $10-45 \mathrm{~cm}$ ) and often waterproof (Wu and Zhang, 2008; Song et al., 2015; Lin et al., 2015). The water thawed during the daytime would freeze again at night on the soil surface (Fig. S10a; Shi et al., 2006; Wu and Zhang, 2010b). The thin-ice layer could stop atmospheric gases of $\mathrm{CH}_{4}$ and $\mathrm{O}_{2}$ from getting into the soils (Gažovič et al., 2010). During autumn, the SWC is $15.3 \%$ at $10 \mathrm{~cm}$ below ground, decreases to $9.4 \%$ at $20-40 \mathrm{~cm}$, and then increases to $13.6 \%$ and $21.0 \%$ at $80 \mathrm{~cm}$ and $160 \mathrm{~cm}$, respectively (Table S1). However, soils are bidirectionally frozen from both the top (ground surface) and bottom (permafrost table), which is about $200-400 \mathrm{~cm}$ below ground (Fig. S8;
$\mathrm{Wu}$ and Zhang, 2010a). On the one hand, the frozen soil of the ground surface (about $0-40 \mathrm{~cm}$ ) prevents the outside liquid water from permeating. On the other hand, the freezing itself will reduce the liquid water content in the soil. Therefore, it creates finely closed anaerobic gaps that allow $\mathrm{CH}_{4}$ and $\mathrm{O}_{2}$ gases into deep soils (about 50-400 cm; Mastepanov et al., 2008, 2013; Zona et al., 2016). Meanwhile, the temperature of deep soils (about $50-400 \mathrm{~cm}$ ) still remains at a relatively high level (Fig. S10b), and methanotrophic bacteria will still be active at this high $T_{\text {soil }}$ (Fig. 2). This could be one important mechanism for autumn soil $\mathrm{CH}_{4}$ consumption. In addition, in principal it is also possible that the observed seasonal variation in $\mathrm{CH}_{4}$ flux may actually arise from the spatial variation in the footprint covered by the EC site (within $175 \mathrm{~m}$ ), given that prevalent wind direction changes seasonally (Fig. S4). Nonetheless, we found that the same vegetation species and soil exist in different directions from the tower within the footprint (Fig. S11). This spatial vegetation and soil homogeneity rules out the potential influence of footprint changes on the sign of $\mathrm{CH}_{4}$ balances and further confirms that seasonal soil freezing and thawing differences may likely be the main explanation for seasonal $\mathrm{CH}_{4}$ variations.

Furthermore, we suggested that the specific autumn soil vertical structure may help to explain why the site was a $\mathrm{CH}_{4}$ sink, unlike the $\mathrm{CH}_{4}$ source in spring. The sequential probing data enables us to establish a rough estimate on the soil vertical structure during the autumn thawing-freezing process, in which the vertical distribution of clay, sandy soils, and soil organic layers was mixed like a multilayer structure, rather than forming a gradual change (Fig. 6e). As the soil profile is vertically different in features such as soil density, thermal conductivity, latent heat, and soil salinity, we boldly conjecture that the $T_{\text {soil }}, \mathrm{SWC}$, and soil microbial activities also had a similar layer type of vertical distribution. As a result, layers of frozen and thawed soils were not changing gradually but appeared like a layered structure too. This soil vertical structure trapped high concentrations of soil water between the frozen layers and was therefore highly anaerobic and suitable for $\mathrm{CH}_{4}$ production. It may also allow speculation that biogenic $\mathrm{CH}_{4}$ between frozen layers could not escape in autumn. The biogenic $\mathrm{CH}_{4}$ would be trapped until the active soil layer was completely frozen in late autumn, and in some warmer years until early winter, and created frost cracks. This would enable it to escape and may explain why there was a large burst of $\mathrm{CH}_{4}$ emissions in late autumn and early winter and may also explain the constantly weak $\mathrm{CH}_{4}$ emission through the winter season, although methanogenic bacteria may have stopped functioning in the low temperatures of winter. Of course, further studies and direct data collection in the field will be needed to fully test the hypothesis. 


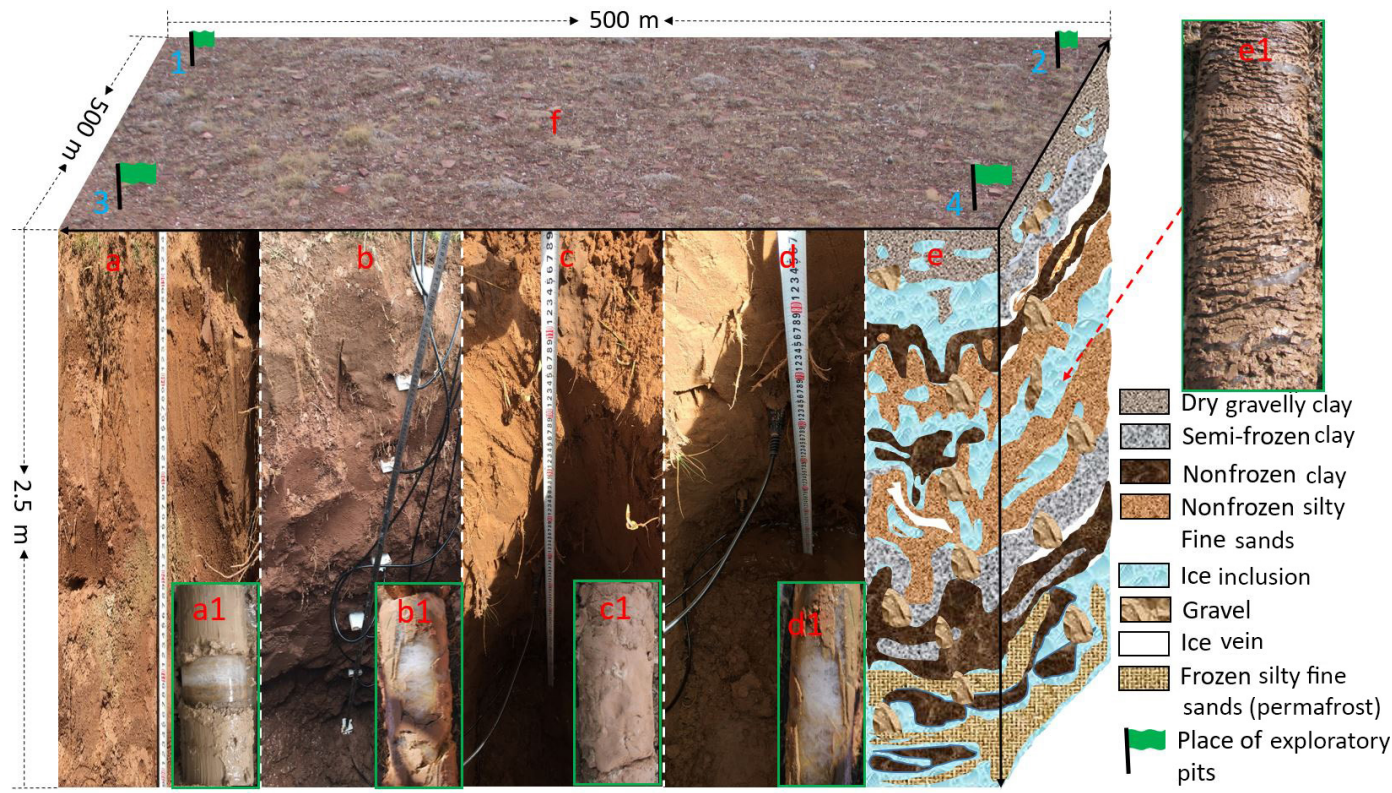

Figure 6. Location of exploratory pits and drillings in this study in autumn: (f) photo of a typical ground surface (16 October 2014). Green flags represent the location for the soil survey using test pits and drilling. (a, b, c, d) Soil profiles of 0-250 cm of depth at the north (1), south (2), east (3), and west (4) corners of the eddy covariance footprint, respectively. (a1, b1, c1, d1) Drilling cores, with clear ice (white) in (a1, b1, d1), but not in (c1). (e) An illustration that combines results from drillings, test pits, and multichannel ground-penetrating radar (Malå Geoscience, Sweden) for active layer variations in permafrost area during the autumn season. (e1) A core sample of the same drilling (16 October 2014).

\subsection{Impacts of environmental, permafrost, and microbial activities on $\mathrm{CH}_{4}$ fluxes}

Our results demonstrated the important roles of climate, freezing and thawing dynamics, and soil microbe activities in regulating the direction and amount of $\mathrm{CH}_{4}$ exchange between the atmosphere and ecosystems in permafrost areas. The key role of the above factors and processes was also confirmed by the better representation of seasonal $\mathrm{CH}_{4}$ cycles by our new seasonal division method based on soil microbes, temperature, and permafrost dynamics rather than $T_{\text {air }}$ or vegetation phenology. Here, we further discuss potential mechanisms of how environmental (including air and soil heat and water), freezing and thawing processes, and soil microbes control the production and absorption of $\mathrm{CH}_{4}$.

First, it is noteworthy that both the strength and direction of correlations among $\mathrm{CH}_{4}$ fluxes, SWC, and $T_{\text {soil }}$ parameters changed with soil depths, particularly during spring and autumn, when active layer soils shifted between thawing and freezing regularly. The positive and negative $\mathrm{CH}_{4}$ flux correlations with $T_{\text {soil }}$ and SWC may suggest that the impacts of $T_{\text {soil }}$ and $\mathrm{SWC}$ on $\mathrm{CH}_{4}$ fluxes shall be treated as a holistic process (Table 3), rather than as separate ones. For instance, in autumn, the significant correlation between $\mathrm{CH}_{4}$ fluxes and $T_{\text {soil }}$ or SWC was positive at some soil depths, but negative at some other depths, reaching the maximum at the depth of $80 \mathrm{~cm}$. Further, in situ observations suggested that soil organic matter and soil microbe number were also at a very high level at this depth, highlighting that the regulation of soil abiotic factors on $\mathrm{CH}_{4}$ cycling may be highly influenced by soil biotic activities. In addition, the holistic soil heat-water process could also determine the concentration of soil inorganic ions, particularly during spring and autumn, which were critical factors controlling the amount of soil unfrozen water. Earlier studies suggested that soil unfrozen water is important for maintaining soil microbial activities in winter (Panikov and Dedysh, 2000; Rivkina et al., 2004). In the future we will include data for soil unfrozen water to test its role in regulating $\mathrm{CH}_{4}$ exchanges in permafrost regions.

$T_{\text {air }}$ and precipitation impact $\mathrm{CH}_{4}$ fluxes indirectly through their influences on $T_{\text {soil }}$ and SWC (Zhuang et al., 2004; Lecher et al., 2015). Such indirect influences may often be characterized with time-lagged effects (Koven et al., 2011). For instance, post-drought rainfall events in summer can first promote soil $\mathrm{CH}_{4}$ consumption (summer of 2014). This is because certain soil moisture is needed for methanogenic bacteria to function (Del et al., 2000; Luo et al., 2012). Yet, prolonged rainfall will eventually cause $\mathrm{CH}_{4}$ fluxes to change from negative (soils consume $\mathrm{CH}_{4}$ ) to positive (soils emit $\mathrm{CH}_{4}$ ) fluxes (for example, day 168 to 183 of 2015; Fig. 3d). After rainfall events, $\mathrm{CH}_{4}$ flux gradually turned negative again with the decrease in SWC. As a result of these timelagged effects, the correlation coefficient between $\mathrm{CH}_{4}$ fluxes 
and precipitation often appears very low, although still statistically significant.

Second, soil methanogenic and methanotrophic bacteria could coexist with different optimal niches (e.g., ranges of $T_{\text {air }} / T_{\text {soil }}$ and SWC; Zhuang et al., 2013; Lau et al., 2015; Wei et al., 2015a). For example, the $\mathrm{CH}_{4}$ diel cycle in summer was found to have two strong consumption peaks and one weak emission peak (Fig. 4a3, c3, d3, e3). The timing of these different peaks may well reflect the different environmental requirements for the dominance of methanogens and methanotrophic bacteria. Furthermore, methanogens may have a broader functional temperature range than methanotrophic bacteria (Kolb, 2009; Lau et al., 2015; Yang et al., 2016). This is also evident, for example, from the diel $\mathrm{CH}_{4}$ cycle in autumn when $\mathrm{CH}_{4}$ consumption was minimal at both the lowest and highest $T_{\text {air }}$ (Fig. 4a4-e4).

The complex relationships between $\mathrm{CH}_{4}$ fluxes and environmental factors make it a grand challenge to predict the future of the QTP $\mathrm{CH}_{4}$ budget under a changing climate. For instance, it has been generally believed that the ALT will increase under projected warming (Wu and Liu, 2004). The positive correlation between $\mathrm{CH}_{4}$ fluxes and ALT found here suggests that the QTP permafrost $\mathrm{CH}_{4}$ sink may thus be weakened. However, the negative correlation between $\mathrm{CH}_{4}$ flux and $T_{\text {air }}$ may lead to a different conclusion. Incorporating our findings and high-resolution data into mechanistic $\mathrm{CH}_{4}$ models is therefore needed to enhance our capacity in predicting future $\mathrm{CH}_{4}$ budgets. Earth system models have been introduced to estimate $\mathrm{CH}_{4}$ dynamics (Curry, 2007; Spahni et al., 2011; Bohn et al., 2015). For example, using a terrestrial ecosystem modeling approach, Zhuang et al. (2004) estimated the average QTP permafrost $\mathrm{CH}_{4}$ sink of $-0.08 \mathrm{~g} \mathrm{C} \mathrm{m}^{-2} \mathrm{yr}^{-1}$, much smaller than our fieldbased $\mathrm{CH}_{4}$ estimate $\left(-0.86 \pm 0.23 \mathrm{~g} \mathrm{CH}_{4}-\mathrm{C} \mathrm{m}^{-2} \mathrm{yr}^{-1}\right)$. Current $\mathrm{CH}_{4}$ models focus on the regulation of $\mathrm{CH}_{4}$ processes by temperature and SWC and usually lack high-resolution data for model parameterization (Bohn et al., 2015). Data interpolation and the use of average values of certain environmental factors are normal practices in most models (Zhuang et al., 2004), which may overlook the impacts of environmental variations on $\mathrm{CH}_{4}$ dynamics. For example, at Beilu'he, $T_{\text {air }}$ on a typical summer day (e.g., 6 July 2013) could vary between -6 and $28^{\circ} \mathrm{C}$, a difference of $34^{\circ} \mathrm{C}$. The resulting diel mean temperature, $17^{\circ} \mathrm{C}$, is beyond the range of methanotrophic bacteria's preferable temperature of $20-30^{\circ} \mathrm{C}$ (Segers, 1998; Steinkamp et al., 2001; Yang et al., 2016). Therefore, models using diel mean temperature as an input may estimate the site as a net $\mathrm{CH}_{4}$ sink. However, field observations show a source with a sink only during a short period (08:30-11:30), on 6 July 2013, because the short period of the sink was offset by the source over the remaining $21 \mathrm{~h}$.

Furthermore, half-hourly SWC was related with the waterproof role by the permafrost layer during spring and autumn (Fig. 6a). However, because of the shortage of high- temporal-resolution data, half-diel or diel mean SWC data are often used in many previous studies (Zhu et al., 2004; Jiang et al., 2010; Wei et al., 2015b), which could not correctly show the regulation of permafrost soil properties that are critical for $\mathrm{CH}_{4}$ dynamics. As another example, $T_{\text {soil }}$ of $0-50 \mathrm{~cm}$ in depth is one of the most important factors related to $\mathrm{CH}_{4}$ fluxes (Mastepanov et al., 2008). However, many studies used $T_{\text {air }}$ or reanalyzed deep $T_{\text {soil }}$ instead (Zhu et al., 2004; Bohn et al., 2015; Oh et al., 2016). Because the active layer is not homogeneous, but with different thermal conductivities during the freezing and thawing process, the use of $T_{\text {air }}$ or deep $T_{\text {soil }}$ brings in large uncertainties in $\mathrm{CH}_{4}$ modeling. Future research needs to improve mechanistic understanding of $\mathrm{CH}_{4}$ dynamics and their biotic and abiotic control factors and to conduct more high-resolution and longterm field monitoring.

\subsection{The classification system of the four seasons for $\mathrm{CH}_{4}$ studies}

Our study also differs from the majority of earlier studies regarding the definition of the seasons (Treat et al., 2014; Wang et al., 2014; Wei et al., 2015a; Song et al., 2015). Here, we adopted a new classification system of the four seasons based on 0-25 cm soil depth bacterial activities (Fig. 2), $T_{\text {soil }}$ of $0-40 \mathrm{~cm}$ (Fig. S6a), and ALT (Fig. S8), rather than the conventional methods based on $T_{\text {air }}$ and vegetation dynamics (Chen et al., 2011; McGuire et al., 2012). Previous studies indicated that changes in $\mathrm{CH}_{4}$ fluxes are regulated by soil microbes, and activities of soil microbes are not limited to the warm season (Zhuang et al., 2004; Lau et al., 2015; Yang et al., 2016). For instance, in March and November, we found the amount of gene expression by methanogens and methanotrophs in $0-25 \mathrm{~cm}$ soils were about $16.8 \%$ and $35.6 \%$ (Fig. 2), respectively, suggesting there are still strong microbial activities during the cold and dry season. Therefore, our new method of defining the four seasons from the top soil biotic and abiotic features better captures the pattern of $\mathrm{CH}_{4}$ dynamics throughout a year.

\section{Conclusions}

Our field data indicate that there was a large $\mathrm{CH}_{4}$ sink in the QTP permafrost area during recent years. The strength of this $\mathrm{CH}_{4}$ sink is larger than found in previous studies in the same region and many high-latitude tundra ecosystems. This study highlights the complexity of environmental controls, including soil heat-water processes, permafrost freezing and thawing dynamics, and soil microbial activities, on $\mathrm{CH}_{4}$ cycling. This complexity implies that linear interpolation and extrapolation from site-level studies could introduce large uncertainties in $\mathrm{CH}_{4}$ flux estimation. Future quantification of $\mathrm{CH}_{4}$ dynamics in permafrost regions needs to account for the effects of complex environmental processes. Our findings also 
highlight the importance of conducting more high-resolution and long-term field monitoring in permafrost regions for better understanding and modeling of permafrost $\mathrm{CH}_{4}$ cycling under a changing climate.

Data availability. The data are available through the corresponding authors and will be made publicly available through the State Key Laboratory of Frozen Soil Engineering Data Center in the near future (http://sklfse.casnw.net/).

Supplement. The supplement related to this article is available online at: https://doi.org/10.5194/tc-12-2803-2018-supplement.

Author contributions. HY, QW, and HJ designed the research. HY, $\mathrm{QZ}$, and AC performed eddy-covariance data analysis and calculations. HY and AC drafted the paper. TY, ZL, YQ, and LL contributed to the interpretation of the results and to the text. YY and GL performed the field data collection. All authors contributed to writing the paper.

Competing interests. The authors declare that they have no conflict of interest.

Acknowledgements. We would like to thank Yongzhi Liu, Jing Luo, Ji Chen, Guilong Wu, Wanan Zhu, Zhipeng Xiao, and Chang Liao for their tremendous help in collecting field data over all these years. We also want to pay tribute and show our gratitude to the late Xiaowen Cui for his contribution to our many field adventures. We thank John McCabe for reading over a previous version of the paper. This study was supported by the National Natural Science Foundation of China (41501083), Key Research Program of Frontier Sciences, Chinese Academy of Sciences (QYZDJ-SSW-DQC011), Opening Research Foundation of Key Laboratory of Land Surface Process and Climate Change in Cold and Arid Regions, Chinese Academy of Sciences (LPCC201307), and Opening Research Foundation of Plateau Atmosphere and Environment Key Laboratory of Sichuan Province (PAEKL2014-C3). Anping Chen acknowledges the support from a Purdue University Forestry and Natural Resources research scholarship.

Edited by: Christian Hauck

Reviewed by: two anonymous referees

\section{References}

Bohn, T. J., Melton, J. R., Ito, A., Kleinen, T., Spahni, R., Stocker, B. D., Zhang, B., Zhu, X., Schroeder, R., Glagolev, M. V., Maksyutov, S., Brovkin, V., Chen, G., Denisov, S. N., Eliseev, A. V., Gallego-Sala, A., McDonald, K. C., Rawlins, M. A., Riley, W. J., Subin, Z. M., Tian, H., Zhuang, Q., and Kaplan, J. O.: WETCHIMP-WSL: intercomparison of wetland methane emis- sions models over West Siberia, Biogeosciences, 12, 3321-3349, https://doi.org/10.5194/bg-12-3321-2015, 2015.

Burba, G. G., Mcdermitt, D. K., and Grelle, A.: Addressing the influence of instrument surface heat exchange on the measurements of $\mathrm{CO}_{2}$ flux from open-path gas analyzers, Glob. Change Biol., 14, 1854-1876, 2008.

Cao, B., Gruber, S., and Zhang, T.: Spatial variability of active layer thickness detected by ground-penetrating radar in the Qilian Mountains, Western China, J. Geophys. Res.-Earth, 122, 574591, 2017.

Cao, G., Xu, X., and Long, R.: Methane emissions by alpine plant communities in the Qinghai-Tibet Plateau, Biol. Lett., 4, 681684, 2008.

Cate, R. B. and Nelson, L. A.: A simple statistical procedure for partitioning soil test correlation data into two classes, Soil Sci. Soc. Am. J., 35, 658-660, 1971.

Chang, R., Miller, C., and Dinardo, S.: Methane emissions from Alaska in 2012 from CARVE airborne observations, P. Natl. Acad. Sci. USA, 111, 16694-16699, 2014.

Chang, S. and Shi, P.: A review of research on responses of leaf traits to climate change, Chinese Journal of Plant Ecology, 39, 206-216, 2015.

Chen, W., Wolf, B., and Zheng, X.: Annual methane uptake by temperate semiarid steppes as regulated by stocking rates, aboveground plant biomass and topsoil air permeability, Glob. Change Biol., 17, 2803-2816, 2011.

Curry, C.: Modeling the soil consumption at atmospheric methane at the global scale, Global Biogeochem. Cy., 21, GB4012, https://doi.org/10.1029/2006GB002818, 2007.

Del, G., Parton, W., and Mosier, A. R.: General $\mathrm{CH}_{4}$ oxidation model and comparisons of $\mathrm{CH}_{4}$ oxidation in natural and managed systems, Global Biogeochem. Cy., 14, 999-1019, 2000.

Dengel, S., Zona, D., Sachs, T., Aurela, M., Jammet, M., Parmentier, F. J. W., Oechel, W., and Vesala, T.: Testing the applicability of neural networks as a gap-filling method using $\mathrm{CH}_{4}$ flux data from high latitude wetlands, Biogeosciences, 10, 8185-8200, https://doi.org/10.5194/bg-10-8185-2013, 2013.

Falge, E., Baldocchi, D., and Olson, R.: Gap filling strategies for defensible annual sums of net ecosystem exchange, Agr. Forest Meteorol., 107, 43-69, 2001.

Foken, T. and Wichura, B.: Tools for quality assessment of surfacebased flux measurements, Agr. Forest Meteorol., 78, 83-105, 1996.

Gažovič, M., Kutzbach, L., and Schreiber, P.: Diurnal dynamics of $\mathrm{CH}_{4}$ from a boreal peatland during snowmelt, Tellus B, 62, 133139, 2010.

IPCC: Climate Change 2013: The Physical Science Basis. Contribution of Working Group I to the Fifth Assessment Report of the Intergovernmental Panel on Climate Change, edited by: Stocker, T. F., Qin, D., Plattner, G.-K., Tignor, M., Allen, S. K., Boschung, J., Nauels, A., Xia, Y., Bex, V., and Midgley, P.M., Cambridge University Press, Cambridge, United Kingdom and New York, NY, USA, 1535 pp., 2013.

Jansson, J. K. and Tas, N.: The microbial ecology of permafrost, Nat. Rev. Microbiol., 12, 414-425, 2014.

Jiang, C., Yu, G., and Fang, H.: Short-term effect of increasing nitrogen deposition on $\mathrm{CO}_{2}, \mathrm{CH}_{4}$ and $\mathrm{N}_{2} \mathrm{O}$ fluxes in an alpine meadow on the Qinghai-Tibetan Plateau, China, Atmos. Environ., 44, 2920-2926, 2010. 
Jin, H., Li, S., and Cheng, G.: Permafrost and climatic change in China, Global Planet. Change, 26, 387-404, 2000.

Jørgensen, C. J., Johansen, K. M. L., and Westergaard-Nielsen, A.: Net regional methane sink in High Arctic soils of northeast Greenland, Nat. Geosci., 8, 20-23, 2015.

Kirschke, S., Bousquet, P., and Ciais, P.: Three decades of global methane sources and sinks, Nat. Geosci., 6, 813-823, 2013.

Kolb, S.: The quest for atmospheric methane oxidizers in forest soils, Env. Microbiol. Rep., 1, 336-346, 2009

Koven, C. D., Ringeval, B., and Friedlingstein, P.: Permafrost carbon-climate feedbacks accelerate global warming, P. Natl. Acad. Sci. USA, 108, 14769-14774, 2011.

Lau, M., Stackhouse, B. T., and Layton, A. C.: An active atmospheric methane sink in high Arctic mineral cryosols, ISME J., 9, 1880-1891, 2015.

Lecher, A. L., Dimova, N., and Sparrow K.,J.: Methane transport from the active layer to lakes in the Arctic using Toolik Lake, Alaska, as a case study, P. Natl. Acad. Sci. USA, 112, 3636$3640,2015$.

Lee, X., Massman, W., and Law, B. (Eds.): Handbook of Micrometeorology: A Guide for Surface Flux Measurement and Analysis, Springer Science and Business Media, Part of the Atmospheric and Oceanographic Sciences Library book series (ATSL), 29, https://doi.org/10.1007/1-4020-2265-4, 2006.

$\mathrm{Li}$, K., Gong, Y., and Song, W.: Responses of $\mathrm{CH}_{4}, \mathrm{CO}_{2}$ and $\mathrm{N}_{2} \mathrm{O}$ fluxes to increasing nitrogen deposition in alpine grassland of the Tianshan Mountains, Chemosphere, 88, 140-143, 2012.

Liebner, S., Zeyer, J., and Wagner, D.: Methane oxidation associated with submerged brown mosses reduces methane emissions from Siberian polygonal tundra, J. Ecol., 99, 914-922, 2011.

Lin, Z., Burn, C. R., and Niu, F.: The Thermal Regime, including a Reversed Thermal Offset, of Arid Permafrost Sites with Variations in Vegetation Cover Density, Wudaoliang Basin, QinghaiTibet Plateau, Permafrost Periglac., 26, 142-159, 2015.

Loescher, H. W., Law, B. E., and Mahrt, L: Uncertainties in, and interpretation of, carbon flux estimates using the eddy covariance technique, J. Geophys. Res., 111, D21S90, https://doi.org/10.1029/2005JD006932, 2006.

Lund, M., Lafleur, P. M., and Roulet, N. T.:Variability in exchange of $\mathrm{CO} 2$ across 12 northern peatland and tundra sites. Glob. Change Biol., 16, 2436-2448, 2010.

Luo, G. J., Brüggemann, N., Wolf, B., Gasche, R., Grote, R., and Butterbach-Bahl, K.: Decadal variability of soil $\mathrm{CO}_{2}, \mathrm{NO}$, $\mathrm{N}_{2} \mathrm{O}$, and $\mathrm{CH}_{4}$ fluxes at the Höglwald Forest, Germany, Biogeosciences, 9, 1741-1763, https://doi.org/10.5194/bg-9-17412012, 2012.

Mastepanov, M., Sigsgaard, C., and Dlugokencky, E. J.: Large tundra methane burst during onset of freezing, Nature, 456, 628630, 2008.

Mastepanov, M., Sigsgaard, C., Tagesson, T., Ström, L., Tamstorf, M. P., Lund, M., and Christensen, T. R.: Revisiting factors controlling methane emissions from high-Arctic tundra, Biogeosciences, 10, 5139-5158, https://doi.org/10.5194/bg-105139-2013, 2013.

Mauder, M., Cuntz, M., and Drüe, C.: A strategy for quality and uncertainty assessment of long-term eddy-covariance measurements, Agr. Forest Meteorol., 169, 122-135, 2013.

McGuire, A. D., Christensen, T. R., Hayes, D., Heroult, A., Euskirchen, E., Kimball, J. S., Koven, C., Lafleur, P., Miller, P.
A., Oechel, W., Peylin, P., Williams, M., and Yi, Y.: An assessment of the carbon balance of Arctic tundra: comparisons among observations, process models, and atmospheric inversions, Biogeosciences, 9, 3185-3204, https://doi.org/10.5194/bg-9-31852012, 2012.

Moncrieff, J., Clement, R., and Finnigan, J.: Averaging, detrending, and filtering of eddy covariance time series, in: Handbook of micrometeorology, edited by: Lee, X., Massman, W., and Law, B., Springer Netherlands, 29, 7-31, 2004.

Muller, S. W.: Permafrost or permanently frozen ground and related engineering problems, Military Intelligence Division Office, Chief of Engineers, U. S. Army, 2, 6-10, 1947.

Oh, Y., Stackhouse, B., and Lau, M.: A scalable model for methane consumption in arctic mineral soils, Geophys. Res. Lett., 43, 5143-5150, 2016.

Panikov, N. S. and Dedysh, S. N.: Cold season $\mathrm{CH}_{4}$ and $\mathrm{CO}_{2}$ emission from boreal peat bogs (West Siberia): Winter fluxes and thaw activation dynamics, Global Biogeochem. Cy., 14, 10711080, 2000.

Papale, D., Reichstein, M., Aubinet, M., Canfora, E., Bernhofer, C., Kutsch, W., Longdoz, B., Rambal, S., Valentini, R., Vesala, T., and Yakir, D.: Towards a standardized processing of Net Ecosystem Exchange measured with eddy covariance technique: algorithms and uncertainty estimation, Biogeosciences, 3, 571-583, https://doi.org/10.5194/bg-3-571-2006, 2006.

Patra, P. K. and Kort, E. A.: Regional Methane Emission Estimation Based on Observed Atmospheric Concentrations (2002-2012), J. Meteorol. Soc. Jpn., Ser. II, 94, 91-113, 2016.

Qin, Y., Wu, T., and Li, R.: Using ERA-Interim reanalysis dataset to assess the changes of ground surface freezing and thawing condition on the Qinghai-Tibet Plateau, Environ. Earth Sci., 75, 1-13, 2016.

Rigby, M., Prinn, R. G., and Fraser, P. J.: Renewed growth of atmospheric methane, Geophys. Res. Lett., 35, 2-7, 2008.

Rivkina, E., Laurinavichius, K., and McGrath, J.: Microbial life in permafrost, Adv. Space Res., 33, 1215-1221, 2004.

Segers, R.: Methane production and methane consumptiona-review of processes underlying wetland methane fluxes [Review], Biogeochemistry, 41, 23-51, 1998.

Shi, P., Sun, X., and $\mathrm{Xu}, \mathrm{L}$. : Net ecosystem $\mathrm{CO}_{2}$ exchange and controlling factors in a steppe-Kobresia meadow on the Tibetan Plateau, Sci. China Ser. D, 49, 207-218, 2006.

Song, W., Wang, H., and Wang, G.: Methane emissions from an alpine wetland on the Tibetan Plateau: Neglected but vital contribution of the nongrowing season, J. Geophys. Res.-Biogeo., 120, 1475-1490, 2015.

Spahni, R., Wania, R., Neef, L., van Weele, M., Pison, I., Bousquet, P., Frankenberg, C., Foster, P. N., Joos, F., Prentice, I. C., and van Velthoven, P.: Constraining global methane emissions and uptake by ecosystems, Biogeosciences, 8, 1643-1665, https://doi.org/10.5194/bg-8-1643-2011, 2011.

Steinkamp, R., Butterbach-Bahl, K., and Papen, H.: Methane oxidation by soils of an $\mathrm{N}$ limited and $\mathrm{N}$ fertilized spruce forest in the Black Forest, Germany, Soil. Biol. Biochem., 33, 145-153, 2001.

Sturtevant, C. S., Oechel, W. C., Zona, D., Kim, Y., and Emerson, C. E.: Soil moisture control over autumn season methane flux, Arctic Coastal Plain of Alaska, Biogeosciences, 9, 1423-1440, https://doi.org/10.5194/bg-9-1423-2012, 2012. 
Tang, Y., Wan, S., and He, J.: Foreword to the special issue: looking into the impacts of global warming from the roof of the world, J. Plant Ecol., 2, 169-171, 2009.

Treat, C. C., Wollheim, W. M., and Varner, R. K.: Temperature and peat type control $\mathrm{CO}_{2}$ and $\mathrm{CH}_{4}$ production in Alaskan permafrost peats, Glob. Change Biol., 20, 2674-2686, 2014.

Vickers, D. and Mahrt, L.: Quality control and flux sampling problems for tower and aircraft data, J. Atmos. Ocean. Tech., 14, 512526, 1997.

Wang, G., Li, Y., and Wang, Y.: Effects of permafrost thawing on vegetation and soil carbon pool losses on the Qinghai-Tibet Plateau, China, Geoderma, 143, 143- 52, 2008.

Wang, S., Jin, H., and Li, S.: Permafrost degradation on the Qinghai-Tibet Plateau and its environmental impacts, Permafrost Periglac., 11, 43-53, 2000.

Wang, Y., Liu, H., and Chung, H.: Non-growing season soil respiration is controlled by freezing and thawing processes in the summer monsoon-dominated Tibetan alpine grassland, Global Biogeochem. Cy., 28, 1081-1095, 2014.

Webb, E. K., Pearman, G. I., and Leuning, R.: Correction of flux measurements for density effects due to heat and water vapor transfer, Q. J. Roy. Meteorol. Soc., 106, 85-100, 1980.

Wei, D., Ri, X., and Wang, Y.: Responses of $\mathrm{CO}_{2}, \mathrm{CH}_{4}$ and $\mathrm{N}_{2} \mathrm{O}$ fluxes to livestock exclosure in an alpine steppe on the Tibetan Plateau, China, Plant Soil, 359, 45-55, 2012.

Wei, D., Ri, X., and Tarchen, T.: Considerable methane uptake by alpine grasslands despite the cold climate: In situ measurements on the central Tibetan Plateau, 2008-2013, Glob. Change Biol., 21, 777-788, 2015a.

Wei, D., Tarchen, T., and Dai, D.: Revisiting the role of $\mathrm{CH}_{4}$ emissions from alpine wetlands on the Tibetan Plateau: Evidence from two in situ measurements at 4758 and $4320 \mathrm{~m}$ above sea level, J. Geophys. Res.-Biogeo., 120, 1741-1750, 2015 b.

Whalen, S. C.: Biogeochemistry of Methane Exchange between Natural Wetlands and the Atmosphere, Environ. Eng. Sci., 22, 73-94, 2005.

Whalen, S. C. and Reeburgh, W. S.: Consumption of atmospheric methane by tundra soils, Nature, 346, 160-162, 1990.

Whalen, S. C., Reeburgh, W. S., and Barber, V. A.: Oxidation of methane in boreal forest soils: a comparison of seven measures, Biogeochemistry, 16, 181-211, 1992.
Wilson K., Goldstein, A., Falge, E., Aubinet, M., Baldocchi, D., P., Berbigier, Bernhofer, C., Ceulemans, R., Dolman, H., Field, C., Grelle, A., Ibrom, A., Law, B. E., Kowalski, A., Meyers, T., Moncrieff, J., Monson, R., Oechel, W., Tenhunen, J., Valentini, R., and Verma, S.: Energy balance closure at FLUXNET sites, Agr. Forest Meteorol., 113, 223-243, 2002.

$\mathrm{Wu}, \mathrm{Q}$. and Liu, Y.: Ground temperature monitoring and its recent change in Qinghai-Tibet Plateau, Cold Reg. Sci. Technol., 38, 85-92, 2004.

$\mathrm{Wu}$, Q. and Zhang, T.: Recent permafrost warming on the Qinghai-Tibetan Plateau, J. Geophys. Res., 113, D13108, https://doi.org/10.1029/2007JD009539, 2008.

$\mathrm{Wu}, \mathrm{Q}$. and Zhang, T.: Changes in active layer thickness over the Qinghai-Tibetan Plateau from 1995 to 2007, J. Geophys. Res., 115, D09107, https://doi.org/10.1029/2009JD012974, 2010a.

Wu, Q. Zhang, T., and Liu, Y.: Permafrost temperatures and thickness on the Qinghai-Tibet Plateau, Global Planet. Change, 72, 32-38, 2010b.

Yang, S., Wen, X., and Shi, Y.: Hydrocarbon degraders establish at the costs of microbial richness, abundance and keystone taxa after crude oil contamination in permafrost environments, Sci. Rep., 6, 37473, https://doi.org/10.1038/srep37473, 2016.

Zhu, X., Zhuang, Q., and Chen, M.: Net exchanges of methane and carbon dioxide on the Qinghai-Tibetan Plateau from 1979 to 2100, Environ. Res. Lett., 10, 085007, https://doi.org/10.1088/1748-9326/10/8/085007, 2004.

Zhuang, Q., Melillo, J. M., and Kicklighter, D. W.: Methane fluxes between terrestrial ecosystems and the atmosphere at northern high latitudes during the past century: A retrospective analysis with a process-based biogeochemistry model, Global Biogeochem. Cy., 18, GB3010, https://doi.org/10.1029/2004GB002239, 2004.

Zhuang, Q., Chen, M., and Xu, K.: Response of global soil consumption of atmospheric methane to changes in atmospheric climate and nitrogen deposition, Global Biogeochem. Cy., 27, 650663, 2013.

Zona, D., Gioli, B., and Commane, R.: Cold season emissions dominate the Arctic tundra methane budget, P. Natl. Acad. Sci. USA, 113, 40-45, 2016. 